\title{
La contratación de rabí Jucé ben Josuá como «Rav» o Marbiztorá de la aljama de Zaragoza (1454)
}

\author{
Asunción Blasco Martínez * \\ Universidad de Zaragoza
}

Cuando revisaba los fondos del Archivo notarial de Zaragoza (en concreto, el registro del notario Miguel Navarro del año 1454), tratando de encontrar nuevos datos sobre el baño que el monarca aragonés poseía en esa ciudad, es decir por casualidad, llamó mi atención uno de los cuadernillos (el que comprende los fols. 613-622), encabezado por este título: Carta de la firma del Rau. Siguiendo la costumbre, solicité fotocopia del mismo. Horas después, cuando procedí a la lectura reposada del material obtenido, me di cuenta de que no había un documento sino dos, pues, además del escrito de contratación ${ }^{1}$ de rabí Jucé ben Josuá al que se refería el epígrafe, se insertaba la misiva que don Juan, rey de Navarra y lugarteniente del rey de Aragón, había enviado a los judíos de esa comunidad obligándoles a adoptar esa decisión.

Los documentos me parecieron muy interesantes, tanto por el asunto -se insertan las condiciones, los derechos y obligaciones de cada una de las partes- como por la inexistencia de noticias de esa índole en una fuente cristiana ${ }^{2}$, pues, tal y como se hace constar en un registro de Cancillería real de $1338^{3}$,

*suni@unizar.es

${ }^{1}$ Más bien era de renovación, pues desde hacía un lustro rabí Jucé ben Josuá venía desempeñando el cargo de «Rav» de la aljama de esa ciudad.

${ }^{2}$ Las noticias que se conservan al respecto no suelen especificar esos detalles. Archivo de la Corona de Aragón [ACA], reg. 713, fol. 107v (1362.XII.2).

${ }^{3}$ Con ocasión de la reclamación presentada en la corte real por Samuel Abenpesat, judío de Valencia, que, tras ejercer como rabino en la aljama de Teruel durante más de un año, no había conseguido cobrar lo que en su día le habían prometido como salario, en enero de 1338 Pedro el Ceremonioso se dirigió al baile de esa ciudad ordenándole intervenir. En esa misiva, se alude al documento de contratación que se firmó en su día que -se decía- estaba «ebrayce scripto», ACA, reg. 593, fol. 81, publicado por A. RuBIó y LLUCH, Documents per l'història de la cultura catalana mig-eval (Barcelona 1908), vol. II, $\mathrm{n}^{\circ}$ LXII, págs. 58-59. 
lo usual era que esos instrumentos se redactaran en hebreo y ante un çofer (o escribano) judío, por lo que rara vez han quedado anotados en caracteres latinos y lengua romance ${ }^{4}$.

La mencionada fuente documental presentaba un valor añadido por la forma en que se habían sucedido los hechos: a mediados del siglo xv (concretamente en 1454), expiraba el contrato que cinco años atrás la aljama zaragozana había suscrito con rabí Jucé ben Josuá para que se hiciera cargo de la dirección espiritual de la misma, y aunque éste deseaba seguir ocupando ese puesto, una facción de la comunidad decidió prestar su apoyo a otro candidato, concretamente a rabí Elías. En aquellos momentos, delicados desde el punto de vista económico y social, la mencionada aljama no podía permitirse el lujo de contratar a más de un rabino, por lo que la confrontación no se hizo esperar. Para evitar males mayores y consciente de las repercusiones que dicho nombramiento podía tener en el futuro para la sociedad judía aragonesa, el infante Juan que a la sazón era rey de Navarra y gobernador general de Aragón y de Sicilia, entre otros títulos, en calidad de lugarteniente de su hermano Alfonso el Magnánimo (que en el ocaso de su vida continuaba viviendo en Nápoles), decidió tomar las riendas de tan espinoso asunto y zanjar el asunto. Es decir que el acuerdo entre la aljama y el rabino se alcanzó tras superar no pocas vicisitudes y por imposición del mencionado don Juan.

Como paso previo, consideré conveniente tratar de identificar al protagonista principal de toda esta historia: rabí Jucé ben Josuá (o Benjosuá), que resultó ser un personaje familiar para algunos filólogos; pero no por este asunto, sino por las desavenencias que había sostenido con el poeta Salomón Bonafed, a quien -según todos los indicios- años antes había disputado y arrebatado el puesto de «Rav» de la aljama zaragozana. Tras constatar la importancia del documento, y con el fin de ahondar en la personalidad de un rabino, más conocido por la imagen que de él había transmitido su más acérrimo enemigo que por los escasos datos exhumados en los archivos, decidí acometer su estudio.

Después de releer la bibliografía existente al respecto (salvo la escrita en hebreo), procedí a revisar la documentación sobre los judíos de Zaragoza que durante años había ido recabando en los archivos, al tiempo que realizaba nuevas catas en los fondos notariales de los años 1430-1460, un perío-

\footnotetext{
${ }^{4}$ En el caso del mencionado Samuel Abenpesat, se dice que se le había contratado «sermocinante seu predicante per unum annum sanctam legem Moysi coram judeis dicte aljame in sinagoga eorum, prout inter judeos est fieri assuetum, et aliter pueris eorum filiis litteras ebraycas edocente». Véase nota 3. 
do que -lo reconozco y lo asumo- no he examinado de forma exhaustiva: por la ingente tarea que ello representa y porque los resultados obtenidos para encontrar el rastro que -se supone-Salomón Bonafed y Jucé ben Josuá deberían haber dejado en los protocolos notariales de esa ciudad, hasta la fecha han sido totalmente negativos. De todo ello doy cuenta en el presente trabajo en el que, al final, he incluido tanto la carta de don Juan, infante de Aragón y rey de Navarra, como el acta notarial levantada en 1454 por el notario Miguel Navarro con motivo de la contratación de Jucé ben Josuá como rabino de la aljama de Zaragoza.

\section{EL «RAV» O MARBIZTORÁ}

No todos los judíos aragoneses que en los siglos XIV y XV ostentaban la titulación de «rabí» ejercían como rabinos. En los documentos medievales cristianos el término «rabí»» se aplica a dos conceptos diferentes: un título y un cargo. Esa ambigüedad ha inducido a algunos estudiosos a formular interpretaciones erróneas ${ }^{5}$, por lo que, antes de pasar a considerar las diferencias y concomitancias existentes entre el rabino principal o «Rav» y los demás, he creído conveniente aclarar el significado de dicho vocablo.

El título «rabí» se otorgaba a los judíos que hubiesen realizado estudios de Torá (escrita y oral) y estuvieran en condiciones de ejercer actividades que exigieran el conocimiento de la Ley judía: se suponía que eran los eruditos, vinculados desde antiguo a los escribas o soferim y dedicados al estudio de las Sagradas Escrituras y a su interpretación. Pero de ellos, sólo unos pocos desempeñaban el cargo de rabino en una sinagoga; algunos dirigían la oración y el canto ( hazanim), otros ejercían como matarifes («rabí de la degüella» o šohet) y los había que enseñaban la lengua hebrea a los niños, formaban parte del tribunal judío (betdín) o desempeñaban las tareas propias del notario-escribano (sofer) ${ }^{6}$.

Para referirse a los judíos que poseían un bagaje de conocimientos bíblicos y talmúdicos considerable, los documentos medievales aragoneses suelen emplear la palabra latina «magister» o su equivalente en romance, «maestre». También se les llamaba «Rav»o «Rahu» tanto en Zaragoza ${ }^{7}$ como en

\footnotetext{
${ }^{5}$ A. Durán Gudiol, La judería de Huesca (Zaragoza 1985), págs. 71-75.

${ }^{6}$ A. A. Neuman, The Jews in Spain. Their Social, Political and Cultural Life during the Middle Ages (Repr., New York 1969), vol. II, págs. 108-110.

${ }^{7}$ F. BAER, Die Juden im christlichen Spanien. Urkunden und Regesten. I. Aragonien und Navarra (Berlin 1929), nº 375, pág. 573 y nº 387, pág. 607.
} 
Calatayud ${ }^{8}$ y Daroca ${ }^{9}$. No obstante, conviene tener presente que en los textos cristianos el sentido del término «maestre» (o maestro) también es ambiguo ${ }^{10} \mathrm{y}$ que la diferenciación entre «maestre» de un lado, y «Rav» de otro, no es del todo clara, pues en ocasiones (pocas, desde luego) se utilizaron como sinónimos ${ }^{11}$. La confusión se acrecienta todavía más en algunos lugares, como Zaragoza, debido a la existencia de ciertos apellidos homófonos («el Rabi», «del Rabí» ${ }^{12}$, «el Rau», etc.) ${ }^{13}$.

El rabinato era el principal cargo religioso de la aljama o, como reflejan los documentos aragoneses de los siglos XIV y XV, un oficio que desempeñaba el maestro de la Ley o «Rav». Los judíos hispanos solían emplear para referirse a él la voz hebrea marbiztorá («el que disemina o difunde la Ley» ${ }^{14}$ ), mucho más precisa ${ }^{15}$. La mayor o menor relevancia del rabinato de una comunidad

\footnotetext{
${ }^{8}$ «Yolans etc., fideli nostro baiulo aljame judeoum ciuitatis Calataiubii salutem et gratiam. Cum ut percepimus aljama ipsius ciuitatis affirmauerit temporibus retrolapsis Salomonem Rauhen, judeum, per rau dicte aljame ad certum tempus et pro certo salario quos quidem tempus est ut percepimus breuiter finiendum, propterea vobis dicimus et mandamus de certa ciencia et expresse quatenus a maiori et saniori parte judeorum dicte aljame seu consilii eiusdem informacionem plenariam recipiatis an dictus Salomonus Reuhen ad rau predicte aljame sufficiens aut decens fuerit et si illum decentem aut sufficientem inueneritis in continenti ad duos annos extunc proxime sequturos, illum in dicta aljama iterum refirmetis cum salario asueto, distringendo ad istud aljamam eandem cum remediis assuetis quousque per nos aliter super ipsis fuerit ordinatum. Quoniam nos sic de certa sciencia fieri prouiderimus et velimus...», ACA, reg. 2044, fols. 115-115v (1389.III.12).

${ }^{9}$ El 24 de febrero de 1386, el infante Juan concedía a maestre Jahudá Figueruela, judío de Daroca, «qui te asseris esse rahu juxta ritum judeorum», licencia para que pudiera excomulgar con «alampni e nidui» a los judíos que le injuriaran de palabra u obra. ACA, reg. 1691, fol. 55v (1386.II.24).

${ }^{10}$ Se emplea para designar no sólo al experto en derecho judío sino al pintor y a los médicos (físicos y cirujanos), tanto judíos como cristianos.

${ }^{11}$ BAER, Die Juden, n 375, pág. 573 y nº 387, pág. 607.

${ }^{12}$ Sobre las casas de Açach el Rabí, véase AHPZ, Juan de Saviñán, 1417, fols. 95-95v.

${ }^{13}$ En 1445 residía en la capital aragonesa un judío llamado Açach el Rau que, en principio, se podía pensar que era el rabino principal de esa comunidad; pero su condición de clavario (o tesorero) de la aljama durante ese año, elimina esa contingencia. AHPZ, Miguel Navarro, 1445, fols. $15 \mathrm{v}-16,170,180$ y 181.

${ }^{14}$ Sobre el título de marbiz Torá (o marbiztorá) en las comunidades sefardíes de Turquía y Oriente Medio, véase M. Benayahu, Marbiz, Torah (Jerusalem 1953), y Neuman, The Jews in Spain, II, págs. 75 y ss.

${ }^{15}$ Aunque algunos estudiosos como Benayahu opinan que su uso es tardío, dicho término ya aparece registrado como sinónimo de «Rav» en algunos responsa de rabí Isaac ben Séset (cits. Neuman, The Jews in Spain, II, págs. 75 y 295), en las ordenaciones castellanas de 1432 (Y. Moreno Koch, «The Taqqanot of Valladolid of 1432», The American Sephardi IX (1978), págs. 84-85), y en la narración autobiográfica que el cabalista Yehudá Hayyat incluye en el prólogo a su 
dependía de la personalidad de su titular, que ocupaba un lugar especial entre los estudiosos de la Torá y en el seno de la aljama, de la que era líder religioso. Por las referencias documentales ${ }^{16}$ que se conservan acerca de la actuación de los principales rabinos de Zaragoza de los siglos XIV y XV (en especial de Isaac ben Séset y Hasday Crescas) y por otras relativas a rabinos de otros lugares del Reino y de la Corona, se sabía que el «Rav» hacía las veces de predicador y árbitro, y aclaraba las dudas que se le consultaban sobre las materias más diversas, especialmente las rituales; dirigía la oración en las festividades más señaladas, enseñaba la ley en la academia rabínica y participaba activamente en la vida de la comunidad, llegando en ocasiones a colaborar en la redacción del reglamento por el que ésta debía regirse ${ }^{17}$; también estaba facultado para aplicar la pena de excomunión en los casos permitidos y ordenados por la ley judía, y constituía un apoyo decisivo para el poder civil ${ }^{18}$. A veces, la interrelación entre el gobierno de la aljama y el «Rav» fue total, y esas dos fuerzas se complementaron y funcionaron juntas (tal aconteció en Zaragoza con Hasday Crescas), lo que en alguna ocasión a la larga generó ciertos roces; en otros momentos, el maestro de la Ley se mantuvo al margen del poder civil, con el que se llegó a enfrentar: así ocurrió en esa misma ciudad con Isaac ben Séset. Pero, en general, el «Rav» era el defensor por antonomasia de la Ley judía, y su opinión era aceptada prácticamente por todos, incluso por el tribunal judío o betdín que, con frecuencia, requería su parecer para dilucidar los asuntos más espinosos y difíciles que se le presentaban ${ }^{19}$.

Naturalmente para ser «Rav» se requerían ciertos requisitos, como un profundo sentido de la justicia, conocimiento de la Ley y capacidad suficiente para dar la interpretación más adecuada de la misma en cada caso concreto. La dife-

comentario a Ma'aréjet ha-Elohut (J. CASTAÑo, «Traumas individuales en un mundo trastornado: El éxodo de R. Yehudah b. Ya'aqob Hayyat (1492-1496)», en Movimientos migratorios y expulsiones en la diáspora occidental (Pamplona 2000), págs. 57-58), entre otros textos anteriores a 1492.

${ }^{16}$ Las referencias literarias utilizadas por Benayahu no le permitieron concretar en qué consistían estas funciones. Así lo reconoce S. Schwarzfuchs en su recensión a la obra de Benayahu, publicada en RÉJ 113 (1954), págs. 86-87.

${ }^{17}$ Hasday Crescas intervino directamente en la redacción de una normativa general para la aljama de Zaragoza. BAER, Die Juden, no 466, págs. 741-743.

${ }^{18}$ Así lo reconoce Neuman para Zaragoza en tiempo de rabí Isaac ben Séset. Neuman, The Jews in Spain, II, pág. 86. Sobre el derecho de los rabinos a aplicar la pena de excomunión y su complejidad, véase ACA, reg. 1645, fols. 177-177v (1386.III.21), y 1648, fol. 92.

${ }^{19}$ Neuman, The Jews in Spain, I, pág. 114, y A. Hershman, Rabbi Isaac ben Sheshet Perfet and his Times (New York 1943), pág. 118. 
rencia entre el el «Rav» y los otros estudiosos de la Torá estribaba en el hecho de que aquél, gracias a sus aptitudes y virtudes personales, había recibido de la aljama, y más concretamente de sus dirigentes, el cargo de líder religioso de la comunidad por medio de un documento en el que -hasta ahora sólo se suponía- se detallaban las condiciones de dicha contratación, es decir el período de duración del mismo, su salario, y los derechos y tareas que debía asumir en función del cargo, del que podía ser depuesto si la aljama lo consideraba oportuno por incumplir lo pactado ${ }^{20}$. En virtud de esa designación, el elegido debía ser respaldado y obedecido por todos los judíos de la aljama, pues gozaba de una posición social muy elevada, por encima incluso de los adelantados que, como se sabe, constituían el gobierno ejecutivo ${ }^{21}$. Por eso no se titulaba «don», sino que recibía un tratamiento especial: «Rav», «maestre» o marbiztorá..., titulación que, según se desprende de la documentación coetánea, se fue consolidando a lo largo de los siglos XIV y XV.

\section{LA CARTA DE DON JUAN}

Los hechos que se narran en el acta notarial de 1454 tuvieron lugar durante los últimos años del reinado de Alfonso $\mathrm{V}^{22}$, monarca aragonés que desde 1432 se había afincado en Nápoles, dejando el gobierno de sus territorios peninsulares primero en manos de su esposa, la reina María, y luego, de forma compartida, entre la soberana (a quien confió el principado de Cataluña y el reino de Mallorca) y su hermano el infante Juan de Aragón, rey de Navarra (los reinos de Aragón y Valencia). Desde agosto de 1454, y hasta junio de 1458 en que se produjo el fallecimiento del rey Alfonso, don Juan ejerció como lugarteniente general suyo en todos los territorios de la Corona de Aragón. Por eso, quien regía los destinos del reino de Aragón en el momento de plantearse el conflicto por el rabinato de la aljama de Zaragoza entre rabí Jucé ben Josuá y rabí Elías, era él: un personaje poco simpático pero muy expeditivo y que, no obstante la situación delicada por la que atravesaba la alta política del

\footnotetext{
${ }^{20}$ Es el caso del leridano Embonjua Hazday, que en 1343 era maestro de la Ley en Zaragoza. RuBió y Lluch, Documents per l'història de la cultura catalana mig-eval, II, pág. 58.

${ }^{21}$ Así lo deduce F. Y. BAER, Historia de los judíos en la Corona de Aragón (s. XIII y XIV) (Zaragoza 1985), págs. 128-129, a partir de diversos retazos documentales.

${ }^{22}$ Sobre dicho monarca, véase el documentado estudio de A. RYDER, Alfonso el Magnánimo rey de Aragón, Nápoles y Sicilia (1396-1458) (Valencia 1992) que, no obstante su amplitud, ni siquiera roza el tema que nos ocupa. 
Reino y de la Corona ${ }^{23}$, decidió finalizar el conflicto suscitado en la aljama de Zaragoza por la designación del «Rav».

A tal efecto, envió a los judíos zaragozanos una carta, datada en Jaca a 25 de julio de 1454, que sin duda llevaba el marchamo de algunos de sus más estrechos colaboradores (concretamente de Pascual de Moros, Jaime Pastor y Antonio Sánchez), pues contenía órdenes muy concretas y de obligado cumplimiento. En vista de la conflictividad suscitada ante la elección de un nuevo líder religioso, don Juan se pronunciaba por rabí Jucé, el candidato que consideraba más idóneo para sus intereses, aunque las razones apuntadas para justificar esa decisión fuesen de otra índole. En efecto, tras destacar los amplios conocimientos que de la Ley tenía el mencionado rabino, el Infante dejaba fuera de toda duda que en aquellos momentos rabí Jucé era la persona más adecuada para atender las demandas de los judíos de Zaragoza. Una comunidad que consideraba singular y muy superior a las otras del reino de Aragón: por su tamaño y por la calidad de sus dirigentes, pues -según él mismo reconocía- todas las demás carecían de sabios de prestigio a los que pedir consejo en caso de necesidad. En su escrito, el lugarteniente también ponderaba la capacidad de que había hecho gala rabí Jucé ben Josuá para desempeñar en solitario todas las funciones inherentes al oficio ${ }^{24} \mathrm{y}$ reconocía que, sólo con él, la aljama cubriría con creces sus necesidades y evitaría los desembolsos superfluos inherentes a contrataciones innecesarias. Para reforzar su disposición, el Infante amenazaba con multa de mil florines a los posibles infractores, al tiempo que ordenaba a los dirigentes judíos de Zaragoza presentes y futuros que anotaran en un libro, que debía custodiar al clavario o tesorero de la misma, el importe de la pensión que decidieran asignar al «Rav» ${ }^{25}$.

La injerencia del poder real en los asuntos internos de las comunidades judías, en general, y de la zaragozana, en particular, no era un hecho nuevo ni aislado, y eso que las aljamas trataron de combatirla desde antiguo ${ }^{26}$ con todos los medios a su alcance. Unos años después (en 1460), sería en Huesca donde los adelantados y miembros de esa comunidad recibirían una misiva de don Juan, ya rey de Aragón, por la que les ordenaba superar sus diferencias, deponer al judío (en ese caso, un extranjero) que previamente habían elegido como rabí, y desig-

\footnotetext{
${ }^{23}$ El soberano de Navarra tenía que hacer frente a varios conflictos contraídos con el reino de Castilla y muy especialmente con su hijo Carlos, príncipe de Viana. Sobre la biografía de tan controvertido personaje, véase J. Vicens Vives, Juan II de Aragón (1398-1479) (Barcelona 1953).

${ }^{24}$ Apéndice documental, fols. $614 \mathrm{v}-615$.

${ }^{25}$ Apéndice documental, fol. $614 \mathrm{v}$.

${ }^{26}$ Tal era el espíritu de las ordenaciones de la aljama de Zaragoza sancionadas en septiembre de 1340 por el rey Pedro el Ceremonioso. En BAER, Die Juden, nº 215, págs. 300-302.
} 
nar como líder religioso a maestre Isaac Arrundí quien, además de ser «persona buena, abil e dispuesta», era natural y vecino de esa ciudad ${ }^{27}$. Es de suponer que la experiencia adquirida por don Juan en la resolución del conflicto suscitado en Zaragoza en 1454 le sería de gran utilidad para solucionar el que años después se produjo en Huesca, y eso que los argumentos empleados para justificar su decisión en este caso fueron completamente distintos de los esgrimidos años antes en la capital del Reino, donde el candidato respaldado por la Corona había sido un forastero siciliano, aunque llevaba varios años al frente del rabinato de esa aljama. Y es que lo que realmente preocupaba al Infante era que el liderazgo de una comunidad como la zaragozana, que a la sazón se hallaba en el punto de mira de todas las demás del Reino y de la Corona, estuviese controlado por alguien de su confianza y que no planteara problemas.

Por eso, resulta hasta cierto punto comprensible que don Juan, acuciado por asuntos varios, tratara de evitar la posible contienda entre los partidarios de Jucé ben Josuá, que desde hacía cinco años ocupaba el cargo de marbiztorá de la aljama de Zaragoza, y los de rabí Elías, que aspiraba a desbancarle, pues se preveía que ese desencuentro podría tener consecuencias lesivas tanto para los intereses de la aljama como para los de la Corona. Es de suponer que, como en anteriores ocasiones similares a ésta, cada uno de los candidatos liderara una de las dos grandes facciones existentes en la comunidad zaragozana: la de los poderosos y la de los menos favorecidos: dos grupos que, desde hacía años, trataban de imponer sus preferencias siempre que se debatían asuntos de interés vital para el colectivo, tales como la reforma fiscal, la participación de los distintos estamentos sociales en la composición del ejecutivo ${ }^{28} \mathrm{o}$ la designación del nuevo líder religioso..., es decir, siempre que el control del poder se ponía en juego ${ }^{29}$.

Entretanto, el rey Alfonso seguía en Nápoles, disfrutando de la vida y apurando sus últimos años en un ambiente de refinada exquisitez y marcado acento renacentista. No sé si motu proprio o por influencia del regente, pero lo cierto es que tres años después de la contratación de Jucé como rabino de Zaragoza (en 1457), el monarca se mostró especialmente generoso con los

\footnotetext{
${ }^{27}$ BAER, Die Juden, $n^{\circ} 547$, pág. 877.

${ }^{28}$ M. Serrano y SAnz, Orígenes de la dominación española en América. Los amigos y protectores aragoneses de Cristóbal Colón (Madrid 1918), págs. CCCCLXXV-CCCCLXXVI (Apéndice $\mathrm{XXX)}$.

${ }^{29}$ Sobre esta conflictividad emergente en determinados momentos de la historia de los judíos zaragozanos, véase E. GuTwIRTH, «Social Criticism in Bonafed's Invective and its Historical Background», Sef 45 (1985), 23-54, especialmente págs. 43-45. 
judíos zaragozanos, a los que concedió una amplia exención tributaria amén de otros privilegios ${ }^{30}$ que, presumiblemente, contribuyeron a incrementar su prosperidad.

\section{LA ALJAMA DE ZARAGOZA}

En el momento en que se produjeron los hechos que se recogen en los documentos de 1454, la aljama zaragozana atravesaba por una fase de declive, sobre todo desde el punto de vista demográfico e intelectual ${ }^{31}$. Su población había disminuido considerablemente debido a las conversiones que, como consecuencia de la llamada Disputa de Tortosa, se habían ido produciendo: primero masivamente ${ }^{32}$ y luego con menor intensidad, aunque de forma continuada ${ }^{33}$. Una parte considerable de los judíos de clase alta se había bautizado o había emigrado, y los que permanecían fieles al judaísmo no estaban interesados en ocupar cargos públicos, pues esas obligaciones les impediría dedicarse a otras tareas más lucrativas. De ahí que quienes desempeñaban los puestos de mayor responsabilidad fueran gentes sencillas: simples artesanos y menestrales que, las más de las veces, carecían de la preparación adecuada ${ }^{34}$. Así lo había denunciado en sus poemas el crítico Salomón Bonafed ${ }^{35}$ cuando, refiriéndose a los miembros del betdín o tribunal judío de Zaragoza, afirmaba: «Los sastres juzgan

${ }^{30}$ Por ejemplo, que no tuvieran que prestar juramento con el rótulo al cuello en pleitos que no superaran los diez sueldos, que no se pudiese sacar de Zaragoza a los judíos presos, etc. Véase SERrano y Sanz, Orígenes, págs. XXXV-XXXVI.

${ }^{31}$ J. M. ${ }^{a}$ Millás Vallicrosa, La poesía sagrada hebraicoespañola (Madrid-Barcelona 1948), pág. 157.

${ }^{32}$ Tal fue la razón aducida por Alfonso el Magnánimo en 1455 y de nuevo en 1460, cuando redujo en un tercio el pago de los 18.000 sueldos que los judíos zaragozanos debían abonarle anualmente en concepto de tributo ordinario. Serrano y Sanz, Orígenes, pág. XXXVII.

${ }^{33}$ Sobre estos dos momentos históricos, véase A. Blasco MARTínez, «El impacto de los ataques de 1391 y del adoctrinamiento de Tortosa en la sociedad judía aragonesa», en III Jornadas hispano-portuguesas de Historia Medieval (Sevilla 1995), págs. 259-288, y EAD., «La conversión de judíos y su repercusión en la sociedad aragonesa durante los primeros años del reinado de Alfonso el Magnánimo», en XVI Congresso Internazionale di Storia della Corona d'Aragona. La Corona d'Aragona ai tempi di Alfonso il Magnanimo. Atti (Napoli 2000), págs. 843-859.

${ }^{34}$ Y. F. BAER, Historia de los judíos en la España cristiana (Madrid 1981), págs. 506 y 763.

${ }^{35}$ Sus poemas satíricos contra los dirigentes de la aljama zaragozana fueron publicados por H. Schirmann, «Hapulmus shel Shelomo Bonafed bi-nejbadé Saragossa», Kobez al Jad IV (XIV) (Jerusalem 1946), págs. 8-64. De todo ello se hace eco Baer en su Historia, pág. 506. Agradezco al Dr. J. Castaño que me ha facilitado algunos de los datos en hebreo procedentes de esta obra utilizados en el presente estudio. 
y los talabarteros son jueces...» Una afirmación teñida de dramatismo que bien podría tratarse de una exageración literaria, aunque algunos documentos coetáneos la ratifican ${ }^{36}$.

Y eso que a mediados del siglo xv, tras la desaparición de las comunidades judías de Barcelona y Valencia, la aljama de Zaragoza ocupaba un lugar preeminente entre las de los territorios de la Corona, a las que -según reconocía el infante don Juan- servía y debía seguir sirviendo de luz y guía. De ahí que se concediera tanta importancia a su líder religioso, pues era a él a quien incumbía la responsabilidad de orientar a todas las aljamas del Reino, en las que -en palabras del mencionado Gobernador general- ya «no hay suficiencia de raus!» ${ }^{37}$. De donde se deduce que, o estamos ante una fórmula puramente retórica, o en el siglo Xv, debido a las conversiones y el exilio de los grupos intelectuales y dirigentes, las en otro tiempo supuestas escuelas rabínicas de Alcañiz y otros lugares del reino de Aragón se habían extinguido.

\section{EL LUGAR DE LOS HECHOS}

Los hechos que se narran tuvieron lugar en la judería de Zaragoza ${ }^{38}, \mathrm{y}$ concretamente en su sinagoga mayor, que era la principal ${ }^{39}$, la de mayor capacidad $\mathrm{y}$, por consiguiente, la más adecuada para congregar a buena parte de los miembros de esa aljama que deseaban -y estaban obligados a ello- conocer el contenido de una misiva real estrechamente relacionada con un asunto que les afectaba directamente: la elección de su líder religioso. Una facultad que, desde hacía más de cien años, venían reivindicando para la comunidad en detrimento de las atribuciones de la Corona, aunque con poco éxito; porque, si bien es cierto que tenían todo el derecho del mundo a realizar la elección libremente, no es menos cierto que, en la práctica y sobre todo en los momentos más conflictivos y decisivos, el monarca seguía imponiendo su voluntad.

\footnotetext{
${ }^{36}$ BAER, Die Juden, $\mathrm{n}^{\circ} 523$.

${ }^{37}$ Apéndice documental, fol. $614 \mathrm{v}$.

${ }^{38}$ No se ha estudiado la aljama zaragozana a mediados del siglo Xv. Para el siglo XIV, véase A. Blasco Martinez, La judería de Zaragoza en el siglo XIV (Zaragoza 1988), y EAD., Los judíos de Zaragoza en el siglo XIV (Tesis doctoral inédita, Universidad de Zaragoza, 1987).

${ }^{39}$ Sobre esta y otras sinagogas de Zaragoza, véase A. Blasco MARTíneZ, «Instituciones sociorreligiosas de los judíos de Zaragoza (Siglos XIV-XV). Sinagogas, cofradías, hospitales», Sef 49 (1989), págs. 227-236, y 50 (1990), págs. 3-46 y 265-288; y EAD., «Las sinagogas de Aragón: datos de los últimos diez años», en Juderías y sinagogas de la Sefarad medieval (Cuenca 2003), págs. 188-227. 
De conformidad con la legislación vigente, que para proceder a la renovación del contrato de «Rav» exigía un mínimo de ochenta individuos, en 1454 se congregaron en Zaragoza en torno a cien judíos de esa aljama para escuchar la lectura de la carta real y seguir sus instrucciones. Gracias a esta presencia masiva y a su registración por parte del notario cristiano, conocemos los nombres de una buena parte de los varones que a mediados del siglo Xv integraban la referida aljama. En primer lugar, figuran los cargos directivos, es decir los adelantados, que en ese momento eran: Samuel Abenlopiel, Jucé Abenabez (desempeñaba el cargo por Bonafós Abnarrabí) y Salomón Alixuilí (en representación de Jacob Galaf); el clavario; los consejeros (Jentó Leví, Samuel Jaba, David Vitales, Mossé Benceví, Jentó de Cortí, Samuel Rapnat, Jacob Nazir, Mossé Aninay (era suplente de Samuel Adich), Jacob Aviayú (en lugar de Jentó Cabez) y Mordehay Amarillo, sustituto de Jacob Senyor); el «Rav» o marbiztorá Jucé ben Josuá, y el nuncio o avisador, que en el caso que nos ocupa era Isaac Zayet ${ }^{40}$. Siguiendo la costumbre, entre los asistentes no había miembros de familias francas (Alazar, Caballería, etc.); en cambio, sí estaban representadas las tres clases sociales o «manos»: mayor, mediana y menor.

La relación alfabética de las familias que respondieron a la convocatoria del gabay es como sigue: Abella, Abenarama, Abenardut, Abenbitas, Abendada, Abenlopiel, Abenpesat, Abiayú, Abotayo, Abnarrabí, Abullamín, Abulfada, Abullacén, Abuzmel, Açafar, Afiá, Aguelo, Albalí, Alcastiel, Alcolumbre, Algranatí, Alpastán, Amato, Aramá, Ardit, Azcarriel, Benarguaz, Benceví, Benjamín, Benatán, Bilforat, Çalama, Canas, Çahadías, Canphí, Capacho, Çarruch, Çarfatí, Chamorro, Cides, Cohén, Cucuf, Darsán, Elí, Falaquera, Far, Farhí, Fichel, Gallur, Halleva, Jaba, Larrabiza, Leví, Mascarán, Moreno, Morfayim, Nagares, Nazir, Orabuena, Patí, Pico, Rapnat, Salinas, Trigo, Vitales y Zunana.

\section{LA CONTRATACIÓN DEL «RAV》 O MARBIZTORÁ (1454)}

De acuerdo con una ordenación que la aljama de Zaragoza había promulgado anteriormente, la elección del «Rav» era competencia de los adelantados y de los consejeros que, junto con al menos otros ochenta miembros de la comuni-

${ }^{40}$ Sobre R. Isaac Zayet y sus discusiones con R. Isaac de León, véase E. GuTwIRTH, «Historia judía e historia de la Inquisición», en Luces y sombras de la judería europea (Pamplona 1996), págs. 206-213. 
dad, debían pronunciarse al respecto de forma unánime. Nadie podría incumplir esa disposición, so pena de incurrir en pena de excomunión (alatma e niduy) ${ }^{41}$.

Todo induce a pensar que rabí Jucé ben Josuá, que, como se ha dicho, ocupaba el cargo desde hacía cinco años, contaba con el apoyo del Infante y de un amplio sector de la población judía, aunque no de su totalidad. Por eso, y con el fin de evitar el enfrentamiento que los seguidores de los aspirantes al rabinato pudiesen protagonizar, el infante Juan decidió intervenir e imponer la candidatura del rabino en funciones que, según parece, le inspiraba más confianza. Ahora bien, para poder hacer efectivas las directrices de la monarquía sin incurrir en las sanciones contenidas en la normativa vigente, era preciso eliminar previamente las cláusulas que pudieran obstaculizar la nominación (en este caso, reelección) de uno de los candidatos. De ahí que los asistentes al acto, con el beneplácito de rabí Jucé ben Josuá, procedieran a suprimir cierta ordenación de la aljama sobre la designación y contratación del «Rav», en virtud de la cual se exigía, bajo pena de excomunión menor (alatma e niduy), que el nominado para ejercer el oficio contara con el voto consensuado de todos los órganos de gobierno (adelantados y consejeros) y de al menos ochenta de sus miembros reunidos en asamblea. Como, según parece, en el caso que nos ocupa no se daban esas condiciones, para evitar el castigo fue preciso derogar la referida disposición.

Acto seguido, y de acuerdo con las órdenes de don Juan, los allí reunidos procedieron a contratar ${ }^{42}$ como «Rav» o marbiztorá a rabí Jucé por un período de diez años a partir del primero de septiembre, con el salario y las condiciones que se expresan en el documento, que al parecer eran idénticas a las que habían suscrito con él en un convenio anterior ${ }^{43}$.

\subsection{Los derechos del «Rav»}

Del contrato de 1454 se deduce que el rabino principal de Zaragoza tenía voz y voto en el organismo rector de la misma y gozaba de indudable predicamento entre los jueces; ejercía la máxima autoridad en todo lo relacionado con el ritual. Para que su dedicación al estudio y a la comunidad no se viera perturbada por tareas más pragmáticas, se le asignó un salario que en 1454 ascendía a 800 sueldos jaqueses anuales (unos 2,5 sueldos diarios), más un suplemento de 90 sueldos de esa misma moneda para gastos de vivienda; cantidad que el

\footnotetext{
${ }^{41}$ La noticia se inserta en apéndice documental, fol. 616v.

${ }^{42}$ Los verbos utilizados son «firmar» y «conduzir». Apéndice documental, fol. 619v.

${ }^{43}$ Tal fue la propuesta del infante don Juan. Véase apéndice documental, fol. 614v.
} 
rabino debería recibir por adelantado y en tres plazos, a saber: a primeros de septiembre, en enero y mayo ${ }^{44}$. Emolumentos que se pueden considerar mesurados si tenemos en cuenta que se trataba de la máxima autoridad religiosa de la principal aljama de la Corona de Aragón. Por eso, no debe causar extrañeza que también se eximiera al marbiztorá del pago de impuestos, concretamente de todo tributo ordinario ${ }^{45} \mathrm{y}$ extraordinario ordenado por el reino, la aljama o la ciudad, entre los que figuraban los que se dedicaban a reparar los muros de esa urbe y a subsanar los gastos ocasionados por los animales exóticos que el rey tenía en el palacio de la Aljafería ${ }^{46}$, que en teoría también debían sufragar otras aljamas ${ }^{47}$. En cuanto a los impuestos indirectos, el «Rav» estaba exonerado del pago de la sisa sobre el vino ${ }^{48}$ («bermello, blanco o cozido» ${ }^{49}$ ) hasta un máximo de ocho cargas de uva, siempre y cuando el producto obtenido fuese para su propio consumo, el de su familia, sus sirvientes y sus invitados: un privilegio que rabí Jucé ben Josuá seguía disfrutando en agosto de 1464, cuando los entonces dirigentes de la comunidad, con consenso del resto de la misma, procedieron a arrendar la sisa del vino de esa aljama al cristiano Alfonso de Navas, como más adelante veremos.

\subsection{Las obligaciones}

En las capitulaciones del contrato de 1454 también se fijaban las obligaciones del «Rav», pues se entendía que el maestro de la Torá debía dedicar todo

\footnotetext{
${ }^{44}$ Apéndice documental, fol. 617.

${ }^{45}$ Como la cena de presencia, que en 1452 ascendió a 260 sueldos jaqueses. AHPZ, Miguel Navarro, fol. $175 \mathrm{v}$.

${ }^{46}$ En ese año, el rey sólo tenía en Zaragoza un león que estaba al cuidado de Esperaindeo Salvador. AHPZ, Miguel Navarro, 1454, fols. 29v-30, 37v y $125 \mathrm{v}-126$.

${ }^{47}$ Aunque algunas aljamas procuraron eludir esta obligación (AHPZ, Miguel Navarro, 1454, fol. 162). Sobre los animales que el rey de Aragón tenía en la Aljafería de Zaragoza, véase A. Blasco MartíneZ, «La casa de fieras de la Aljafería de Zaragoza y los judíos», en El poder real en la Corona de Aragón, XV Congreso de Historia de la Corona de Aragón (Zaragoza 1996), vol. III, págs. 291-318.

${ }^{48}$ En ese año de 1454, el arrendador de la sisa del vino de la judería era Pascual Melero. AHPZ, Miguel Navarro, fol. 29v.

${ }^{49}$ Sobre la producción del vino entre los judíos aragoneses, véase A. Blasco MarTínEZ, «La producción y comercialización del vino entre los judíos de Zaragoza (Siglo XIV)», AEM 19 (1989), págs. 405-449.
} 
su tiempo a la comunidad que, precisamente por eso, le pagaba un salario: para que pudiera centrar su vida en el estudio y conocimiento de la Ley, y en su difusión.

Como líder religioso de los judíos zaragozanos, rabí Jucé debería pronunciar un mínimo de doce sermones a lo largo del año (sábados o festivos), a ser posible uno al mes, en alguna de las sinagogas u oratorios (midrasim) de la ciudad: allí donde decidieran sus correligionarios. $\mathrm{El}$ «Rav» quedaba asimismo obligado a enseñar la Ley a los niños ${ }^{50}$ en su estudio ${ }^{51}$, siempre que fuese requerido para ello y de acuerdo con el horario siguiente: los tres primeros días de la semana (domingo, lunes y martes), se comprometía a explicar una lección del Talmud, la que él decidiese, pero a distinta hora según el período estacional: en verano lo haría durante el día y en invierno por la noche; el resto de las jornadas laborables (miércoles a viernes), impartiría las enseñanzas dentro de ese mismo horario. Como se sobreentendía que su labor como maestro también incluía a los adultos, se acordó que los Sabatot que no pronunciara sermón el rabino debería dedicarlos a disertar y debatir sobre un fragmento de la Haftará (Profetas) de extensión razonable con cuantos acudieran a su casa: por la mañana, antes de la oración, y por la tarde, con antelación al rezo de vísperas ${ }^{52}$.

El rabino no podría desviar su atención de las Escrituras con el pretexto de dedicar ese tiempo a enseñar ciencias profanas, pues era del dominio público que el estudio de la Torá estaba -y debía seguir siendo así- muy por encima del de las ciencias y la filosofía. Tampoco le estaba permitido aducir impedimentos falsos con el fin de justificar la desatención de sus obligaciones docentes para con la aljama durante el horario concertado con ella, sobre todo si lo que hacía a lo largo de esa franja horaria era enseñar materias profanas a otros discípulos y en otro lugar. Por su condición de líder religioso, el marbiztorá estaba obligado a platicar cuando sus correligionarios lo consideraran oportuno y sobre el tema que ellos propusieran, pero siempre que se lo solicitaran con al menos cuatro días de antelación. Asimismo asumía el rabino que, en el caso de producirse el fallecimiento de algún miembro de la comunidad, dispondría de menos tiempo para preparar la plática del entierro..., no obstante, y con el fin de evitar el estrés que dicha situación le pudiera ocasionar, se introdujo en el convenio una cláu-

${ }^{50}$ Años atrás, la aljama de Zaragoza contaba con un rabí que se ocupaba de enseñar a los niños. En 1425 se titulaba «rabi de ninyos» el sastre Açach Hamiç (AHPZ, García Gavín, 1425, fol. 97), y en 1429 ejercía ese mismo cometido Jentó Gallipapa (AHPZ, García Gavín, 1429, fol. 220).

${ }^{51}$ El término empleado es «estudio». Apéndice documental, fols. 618-618v.

52 Apéndice documental, fol. 618. 
sula por la cual la aljama se comprometía a notificar al rabino las defunciones habidas lo antes posible ${ }^{53}$.

Además de ilustrar y enseñar con la palabra y el ejemplo dentro y fuera de la escuela, el «Rav» era el responsable máximo de los escritos institucionales de la comunidad: por eso, debía ocuparse de revisar la redacción de las cartas y documentos de alto nivel cuando los adelantados se lo solicitaran. También era de su incumbencia aconsejar a los jueces (berolins o berorins), participar en sus deliberaciones y contribuir a la elaboración de sus sentencias: tareas generalmente enjundiosas, por lo que el rabino solicitaba tiempo suficiente para su correcta ejecución ${ }^{54}$.

Rabí Jucé se comprometía a residir en Zaragoza mientras el convenio permaneciese vigente. De hecho, sólo podría ausentarse de la ciudad por causa grave y por un periodo de tiempo breve. En el documento de contratación no se contemplaba el derecho al disfrute de días vacacionales, aunque el rabino se reservaba la opción de abandonar la ciudad siempre que lo considerase oportuno sin necesidad de dar demasiadas explicaciones ni solicitar licencia previa a los adelantados. También se hacía constar en el acuerdo que si en el transcurso del mismo se producía en Zaragoza una epidemia, el rabino podría abandonar la ciudad con toda su parentela y fijar su residencia en un lugar más seguro hasta que remitiera la enfermedad ${ }^{55}$.

El «Rav» estaba facultado para lanzar pena de excomunión en la sinagoga, pero su poder no era omnímodo, sino que estaba controlado por el organismo ejecutivo de la aljama y por los jueces, cuya aquiescencia previa precisaba para poder ejercer la referida atribución.

Tanto la aljama como el rabino se obligaron a cumplir lo pactado y a correr con los gastos que su negligencia o irresponsabilidad pudiesen ocasionar. Por su parte, la comunidad y sus dirigentes ofrecieron como garantía sus bienes y rentas, y renunciaron a sus jueces locales aceptando la jurisdicción del rey y de sus representantes que, en orden jerárquico descendente, eran: el lugarteniente y gobernador general, el justicia de Aragón, el merino de Zaragoza, etc.; asimismo, declinaron toda clase de privilegios, ordenanzas y decretos que pudieran resultarles beneficiosos en relación con este asunto; finalmente, y con el fin de garantizar al máximo el cumplimiento del contrato suscrito, recurrieron a tomar quiñán de los testigos Sentó Cohén y Abraham Moriel, de acuerdo con la

\footnotetext{
${ }^{53}$ Apéndice documental, fol. 618v.

${ }^{54}$ Apéndice documental, fols. 618v-619.

${ }^{55}$ Apéndice documental, fols. 619-619v.
} 
fórmula utilizada en el mundo contractual judío, para tranquilizar al acreedor y garantizar su cumplimiento.

También rabí Jucé se avino a aceptar las condiciones estipuladas en el contrato y, tras presentar todos los avales exigidos, se obligó a cumplir lo acordado y a correr con los gastos que, llegado el caso, su conducta inadecuada pudiese generar. Asimismo, se comprometió a no cambiar de domicilio en los siguientes diez años ${ }^{56}$.

\section{LOS PROTAGONISTAS}

Como he apuntado anteriormente, que se produjeran divergencias entre los componentes de la aljama en el momento de elegir a su líder religioso no era un hecho anómalo, al menos por lo que respecta a Zaragoza, donde, según todos los indicios, se había producido un hecho similar a éste unos años antes, seguramente en la década de los años cuarenta ${ }^{57}$. Sólo que, en aquella ocasión, uno de los aspirantes al cargo había sido el poeta Salomón Bonafed, que acabó siendo derrotado por su adversario: un judío que, según relata el citado Salomón, se llamaba rabí Yosef ben Yešu'á, es decir igual que el rabino que en 1454 disputó a rabí Elías el rabinato de la aljama de Zaragoza. Curiosa coincidencia que -como he dicho- me ha llevado a indagar sobre los personajes mencionados en el documento y muy especialmente sobre esos dos individuos homónimos (rabí Jucé ben Josuá y rabí Yosef ben Yešu á), con el fin de averiguar si existía alguna conexión entre ellos.

\subsection{Rabí Jucé ben Josuá de Sicilia}

El protagonista principal de toda esta historia es rabí Jucé ben Josuá, que en 1454 era candidato y «Rav» en funciones, pues desde hacía cinco años venía desempeñando el oficio de «Rav» o marbiztorá en Zaragoza. Lo único que he conseguido averiguar sobre él a través de la documentación notarial es que, en uno de los artículos de las capitulaciones para el arriendo de la

\footnotetext{
${ }^{56}$ Apéndice documental, fols. 620-621v.

${ }^{57}$ Sería antes de 1445, pues, según Saénz-Badillos, Bonafed fue expulsado ese año de Zaragoza por rabí Yehosúa (sic, por rabí Yosef ben Yešu 'á). A. SÁEnz-BADILlos, «Selomoh Bonafed, último gran poeta de Sefarad, y la poesía hebrea», E-Humanista 2 (2002), pág. 3. 
sisa del vino de esa comunidad suscritas en $1464{ }^{58}$, que se incluye a continuación, se le eximía del pago del impuesto de la sisa sobre ocho cargas de uva para consumo propio y de los de su casa:

Que el Rau rabi Jucef ben Josua pueda poner para prouision de su casa y de todos los comensales con el, todo frau cesant, ocho cargas de vuas de cada setze pesas, las quales ocho cargas de vuas pueda fazer vino vermello, blanco, cozido, ros e todo lo que bien visto le sera, sin pena alguna, e assi mismo pueda fazer de las ditas ocho cargas de vuas, malluelos remalluelos tantos quantos vistos les seran beuer aquel vino malluelo, remalluelos, el et todos los comensales de su casa; de las quales ocho cargas de vuas ni del vino ni malluelos que de aquellas sacara o fara no sea tenido pagar sisa alguna ni dar manifestacion de aquellas ni del vino ni malluelos que de aquellas fara, ni le pueda seyer feyta enquesta ni enquestas algunas, acceptado que si el gabellador querra que el dito Rau ne faga sagrament, que el ni otri por el por interposita persona alguna, directament ni indirecta frau alguno no faze ni fara a la dita sisa ni al gabellador no de poner mas de las ditas ocho cargas ni de dar del vino o malluelos que de aquellas procura a ningun pechero, si ya no es con conuit licito en su casa, que aquel jurament sea tenido fazer todo hora que por el gabellador sera requerido o por su menestral vna vez en el anyo de la dita gabella, hoc y encara ordena que si del dito vino restara al dito Rau pora passado el anyo de la dita gabella, que aquel pueda beuer, como dito es, sinse pagar sisa alguna de aquel rendador que sera ni sinse dar manifestacio alguna de aquel ${ }^{59}$.

Esta provisión, que coincide con lo que -según hemos visto- años antes (en 1454) se había estipulado en el contrato firmado entre el rabino y la aljama, constata la presencia de rabí Jucé ben Josua como «Rav» o marbiztorá de la aljama zaragozana diez años después, es decir en 1464. Posición que, de conformidad con cierta noticia deslizada en el proceso inquisitorial contra el vicecanciller Alfonso de la Cavallería, se prolongó unos años más: en efecto, durante el men-

${ }^{58}$ Concretamente, en el titulado «Capitol de las ocho cargas de vuas del Rau».

${ }^{59}$ AHPZ, Antón Maurán, 1464, fols. 266-267. Las capitulaciones completas que se firmaron en dicha ocasión, se conservan en hebreo y en caracteres latinos en el AHPZ. Las latinas fueron publicadas, con algunos errores de transcripción (así, se leyó «rabí Jucef Bensefis» cuando en realidad pone «rabí Jucef Benjosuá») por SERRANO Y SANZ con el título de «Capitulaciones para el arriendo de la sisa del vino de la judería de Zaragoza, desde el 26 de septiembre de 1464 a igual fecha de 1465», Memorias de la Facultad de Filosofía y Letras I (Zaragoza 1922-23), págs. 366368. Ese mismo autor se refirió de nuevo a ellas, sintetizando su contenido, en Orígenes, págs. XXIII-XXIV. Recoge la noticia BAER, Historia, pág. 763, nota 5. 
cionado sumario, se recoge la declaración que en 1488 formulara ante el tribunal inquisitorial Mossé Aninay, hijo de Crescas Aninay, habitante de Arándiga; aseguraba este judío haber oído comentar al vicecanciller ${ }^{60}$ poco después de ser objeto de un intento de agresión que, no obstante la gravedad de cuanto le había acaecido, se sentía protegido y seguro por un amuleto («nómina» o quimiha) que le había entregado «el rav viejo ciciliano, rabi que teniades en esta aliama, fecha a mi nombre y contra enemigos» ${ }^{61}$. Dadas las circunstancias y el tiempo transcurrido, el rabino siciliano, ya anciano, podía ser Jucé ben Josuá.

$Y$ en efecto, todos los estudiosos que de alguna manera se han acercado al tema identifican al mencionado rabino siciliano con Yosef ben Yešu'á. El primero que apuntó esa posibilidad fue Schirmann, en 1946: en su introducción a la edición de las composiciones poéticas que el poeta Salomón Bonafed escribió contra algunos dirigentes de Zaragoza, este historiador de la literatura hebrea afirmaba que esos poemas habían sido redactados en el transcurso de la polémica sostenida entre Bonafed y sus partidarios, de un lado, y el bando de sus oponentes, liderado por un «nativo de Sicilia, llamado Yosef Yešu á, que se había ganado el favor de los notables en la capital de Aragón que le admitieron como instructor rabínico»» ${ }^{62}$, de otro.

Los investigadores que, después de Schirmann, se han dedicado a estudiar a Bonafed y su obra poética, también consideran que fue el rabí siciliano y su comunidad de pietistas quienes, en los años cuarenta, presionaron al poeta y le forzaron a marcharse de Zaragoza ${ }^{63}$. Y si, como hemos visto, quien lideraba la aljama zaragozana en la década de los años sesenta era un rabí siciliano que aparece registrado en los protocolos notariales zaragozanos de esos años con el nombre de Jucé ben Josuá, será preciso admitir que, no obstante las diferencias registradas al escribir el nombre del rabino en los textos hebreos (Yosef Yešu'á, Yosef ben Yešu'á) y en los documentos coetáneos (Jucé Josuá, Benjosuá o ben Josuá), se trata de un solo individuo: el mismo que en la década de los cuarenta arrebató el rabinato de Zaragoza a Salomón Bonafed. Una derrota que éste siempre consideró injusta y a la que, seguramente por eso, dedicó buena parte de su producción poética.

\footnotetext{
${ }^{60}$ En el transcurso de una visita que años atrás había realizado a su casa en compañía de su padre.

${ }^{61}$ Publicado por BAER, Die Juden, pág. 455. Recoge la noticia Gutwirth, «Social Criticism», pág. 29 , nota 34 .

${ }^{62}$ SCHIRMAnN, «Hapulmus shel Shelomo», págs. 11-12.

${ }^{63}$ A. M. ${ }^{a}$ Bejarano, «S $\mathrm{e} l o m o h$ ben Reuben Bonafed poeta y polemista», Anuari de Filologia, vol. XIV, Sección E, n 1 (1991), págs. 92 y 100; E. GutwirTH, «Italy or Spain? The Theme of Jewish Eloquence in Shevet Yehudah», en D. T. Carpi Jubilee Volume (Tel-Aviv 1997), págs. 54-55; A. SÁENZ-BADILLos, «Entre Sefarad e Italia: Selomoh Bonafed, poeta hebreo catalán (siglo xv), y la cultura italiana», Cuadernos de Filología italiana. Número extraordinario (2000), pág. 194, e ID., «Selomoh Bonafed, último gran poeta de Sefarad», pág. 3. 
En relación con cuanto hasta ahora se ha dicho, considero oportuno hacer una observación sobre el nombre del rabino que nos ocupa: y es que, tanto la denominación Jucé ben Josuá, con que se le designa en las fuentes notariales zaragozanas, como la de Yosef Yešu á, empleada en los textos literarios, son de carácter patronímico: un sistema muy poco utilizado por los judíos en el reino de Aragón, donde se prioriza el nombre de familia o gentilicio. Sin embargo, y siempre a partir de la información que proporciona Salomón Bonafed, parece - $\mathrm{o}$ al menos algunos estudiosos lo han interpretado así- que su rival se apellidaba Galuf: en efecto, al final de uno de sus poemas sin rima, Bonafed hace constar que lo había enviado a los líderes rebeldes de Zaragoza con el fin de «pregonar la frivolidad de Yosef Galuf, llamado Yešu á»» ${ }^{64}$. Desconozco el origen de este apellido (Galuf), que el propio Salomón vocaliza, porque no está documentado en Zaragoza donde, por esos mismos años, sí se registran los gentilicios Golluf ${ }^{65}$ y Galaf ${ }^{66}$, muy similares a ése aunque distintos. Claro que, si aceptamos que -como asegura el poeta- rabí Yosef Yešu á había venido de Sicilia, su nombre de familia no tenía por qué estar registrado de antemano en Aragón, sino en la mencionada isla. Y desde luego a comienzos del siglo Xv allí lo estaba, como nombre propio y como apellido ${ }^{67}$ : en 1425 residía en Palermo un individuo que se llamaba Jucé de Galufa, aunque no parece tener nada que ver con el rabino ${ }^{68}$.

De momento, no he conseguido encontrar datos que permitan conocer la ascendencia familiar de Jucé ben Josuá ${ }^{69}$. En cualquier caso, tanto si se apelli-

${ }^{64}$ Schirmann, «Hapulmus shel Shelomo», al final del poema nº 1, pág. 23. Recoge la noticia Gutwirth, «Social Criticism», págs. 23 y 29.

${ }^{65}$ Registrado en Zaragoza ya en el siglo XIII. Tal fue el gentilicio de Alazar (Golluf), que fuera regente de la tesorería de la reina Violante.

${ }^{66}$ En el arriendo de la sisa del vino de la aljama de Zaragoza de 1434, uno de los arrendatarios fue Jacob Galaf, hijo de Jucé (véase Serrano y Sanz, Orígenes, pág. CCCCLXIII). En 1454 figura como suplente de uno de los adelantados de la aljama de Zaragoza (Apéndice documental, fol. 613), ciudad en la que seguía afincado en 1462 (SERrano y SAnZ, Orígenes, pág. LXXXII). En 1461 residía en Zaragoza el comerciante de paños Salomón Galaf, que era proveedor del Príncipe de Viana. Véase M. Gual Camarena, «Notas y documentos sobre el Príncipe de Viana. Apéndice documental», Hispania 82 (1961), págs. 189-231.

${ }^{67}$ S. Simonsohn, The Jews in Sicily, vol. IV: 1415-1439 (Leiden-Boston 2002). Véase Index of Persons, s.v. Benedetto Gallufo y Gallufo (Bina, Cuynu, de Merdoc, de Siracusa y Taguil).

${ }^{68} \mathrm{El}$ documento lo recoge S. Simonsohn, en The Jews in Sicily, vol. IX: Corte Pretoriana and Notaries of Palermo (Leiden-Boston 2006), p. 5867. Agradezco la noticia y el dato a J. Castaño.

${ }^{69}$ La hipótesis de que pudiera ser hijo de rabí Josua Benacrami (Carmi), médico real que en 1446 fue designado por el soberano juez supremo de todos los judíos de Sicilia, no es viable, pues un año antes el mencionado rabino había obtenido licencia para contraer segundo matrimonio, porque su primera mujer era estéril. S. Simonsohn, The Jews in Sicily, vol. V: 1440-1457 (Leiden- 
daba Galuf como si no, y tanto si era natural de Sicilia como si había nacido en la península Ibérica y luego se había trasladado a la isla para regresar al cabo de unos años a ese lugar de origen, lo cierto es que, por cuanto aquí se ha expuesto y porque parece poco probable que a mediados del siglo xv llegaran a Zaragoza procedentes de Sicilia dos rabinos de igual nombre, similar formación e idénticas aspiraciones, considero que el individuo que disputó el rabinato de la aljama de esa ciudad primero a Salomón Bonafed y luego a rabí Elías eran una sola persona: la misma que, años después, en el momento de producirse el atentado (frustrado) contra el vicecanciller Alfonso de la Cavallería, seguía ocupándose de la dirección religiosa de esa comunidad, aunque ya se le consideraba anciana.

\subsubsection{Imagen de Yosef Yešu 'á proyectada por Salomón Bonafed}

Llegados a este punto, y a falta de documentos que nos ilustren sobre rabí Jucé ben Josuá, parece oportuno pasar a analizar los datos que sobre su personalidad proporcionan los escritos de su adversario, el poeta Salomón Bonafed. Conviene advertir que, por tratarse de textos (que no documentos) y por proceder de su enemigo más acérrimo y visceral, la información que proporcionan puede adolecer de la objetividad que toda fuente documental requiere y que, en consecuencia, su veracidad podría dejar bastante que desear.

$\mathrm{Y}$ es que, tras conocer que los miembros de la aljama de Zaragoza preferían al rabí siciliano para el puesto de «Rav», Salomón Bonafed, despechado e indignado ante lo que él consideraba una afrenta imperdonable para su persona y su obra ${ }^{70}$, en 1445 se refugió en Belchite, donde escribió un polémico opúsculo contra los principales judíos de aquella ciudad, que luego distribuyó entre sus amigos y conocidos. La obra, en prosa rimada y poemas, consta de diez partes cada una de las cuales va encabezada por una dedicatoria en la que se da el nombre del referenciado; se facilitan todo lujo de detalles para que el lector pueda identificar fácilmente a la víctima contra la que iba dirigida su sátira, siempre mordaz y en ocasiones despiadada y grosera ${ }^{71}$.

Boston 2003), n 2758, 2788 y 2857. Tendría bastante más que ver con nuestro personaje una carta de recomendación que, en nombre de los «dirigentes de la santa comunidad de Zaragoza», suscribió Yosef ben Sem Tob ben Yešu'á, inserta en una colección epistolar de procedencia hispano-judía, (Ms Praga), cit. GutwiRTh, «Social Criticism», pág. 29, nota 34.

${ }^{70}$ Según dejó escrito en algunos de sus poemas. SÁEnz-BAdillos, «Selomoh Bonafed, último», pág. 12.

${ }^{71}$ Bejarano, «S $\mathrm{e} l o m o h$ ben Reuben Bonafed», pág. 100. 
Bonafed orientó sus dardos más afilados contra Jucé, su rival más directo, a quien tachó de hipócrita y demagogo ${ }^{72}$ amén de otras muchas lindezas. Con el fin de enfrentarle a la masa pasiva y sufriente de la población, lo presentó como líder del grupo dirigente responsable de la administración fraudulenta por la que atravesaba la aljama zaragozana y lo acusó de robar los fondos de la caridad. No contento con esto, acuñó una imagen física de su contrincante realmente penosa, al describirlo como una persona de baja estatura, «pequeña como la de una babosa, sin un solo hueco, sin cuerpo ni proporciones». En cuanto a sus gustos e inclinaciones, llegó a decir que era bebedor y glotón, capaz de coger dinero de las limosnas para llenar su vientre de vino ${ }^{73}$ y de sucumbir a las peores desviaciones sexuales, como la homosexualidad ${ }^{74}$. En cierta ocasión reprobó su forma de vestir y sus ademanes, al representarlo como una especie de fantoche, «subiendo a la tribuna de la sinagoga de Zaragoza vestido con ropa extraña, con amuletos cabalísticos alrededor del cuello y un talith roto en el gran Sabbath anterior a Pésaj, predicando su sermón durante seis horas y gritando, mientras su audiencia le miraba sentada, sin entender y con respeto, como si su rostro fuera de oro...» ${ }^{75}$. Aunque es posible que la indumentaria del rabino fuese distinta de la que usualmente llevaban los judíos de Zaragoza ${ }^{76} \mathrm{y}$ que sus gestos o su tono de voz no fuesen del agrado de toda la concurrencia, salta a la vista la obsesión del poeta por transmitir a la posteridad una imagen física, moral e intelectual de rabí Jucé totalmente negativa ${ }^{77}$. Ese mismo espíritu impregna la composición que Bonafed envió a Vidal de la Cavallería, quien fuera su amigo y compañero en el arte de la poesía hebrea ${ }^{78}$, donde decía así:

Cuando habité por algún tiempo con los judíos miserables de Zaragoza, ellos en su malicia se hicieron un novillo de fundición y trocaron su gloria

\footnotetext{
${ }^{72}$ Gutwirth, «Social Criticism», pág. 33.

${ }^{73}$ Gutwirth, «Social Criticism», pág. 36, y A. Prats Oliván, «La sátira y la invectiva en el diwan de R. Selomó bar Reubén Bonafed», Sef 66 (2006), págs. 83-84.

${ }^{74}$ En la carta que Bonafed envió a Jacob Albalá para advertirle de la pretendida homosexualidad de rabí Yesuá, emplea un lenguaje áspero y subido de tono: «Y aún me causa más dolor el hecho de que a esa cosa hedionda, inaceptable, le gusten los muslos de los varones. Siendo tu un hombre agradable, con bellos ojos, ¿quién sabe si os acostáis juntos, o si su mala inclinación arde por Jacob cual fuego ardiente?», Prats Oliván, «La sátira y la invectiva», pág. 84.

${ }^{75}$ Gutwirth, «Italy or Spain?», págs. 35-67, y SÁEnZ-BAdillos, «Entre Sefarad e Italia»,

${ }^{76}$ Gutwirth, «Social Criticism», pág. 27.

${ }^{77}$ Gutwirth, «Social Criticism», págs. 33-36.

${ }^{78}$ Tras recibir el bautismo, Vidal pasó a llamarse Gonzalo de la Cavallería. A. BlasCo MARTínEz, «Mujeres judías zaragozanas ante la muerte», Aragón en la Edad Media IX (1991), págs. 88-93.
} pág. 203. 
por una imagen de toro, un hombre lleno de artimañas y desprovisto de humanidad, llamado Yosef Yesuá, ¡sepárelo el Señor para mal!, que vino de Sicilia y no sabía por qué vía se reparte la luz del conocimiento ${ }^{79}$.

Un escrito evidentemente metafórico, pero que no deja lugar a dudas sobre los sentimientos que el rabino siciliano inspiraba al poeta. Poco después, Bonafed se trasladaba a Belchite, desde donde siguió increpando a rabí Jucé, a quien, en nuevos escritos llenos de resentimiento y marcada hostilidad, culpabilizaba de sus desgracias personales y de todos los males que afligían a la judería hispana, de ahí que se dirigiera a él en tono altivo, conminándole para que regresara a su país y abandonara la península Ibérica, con estas palabras:

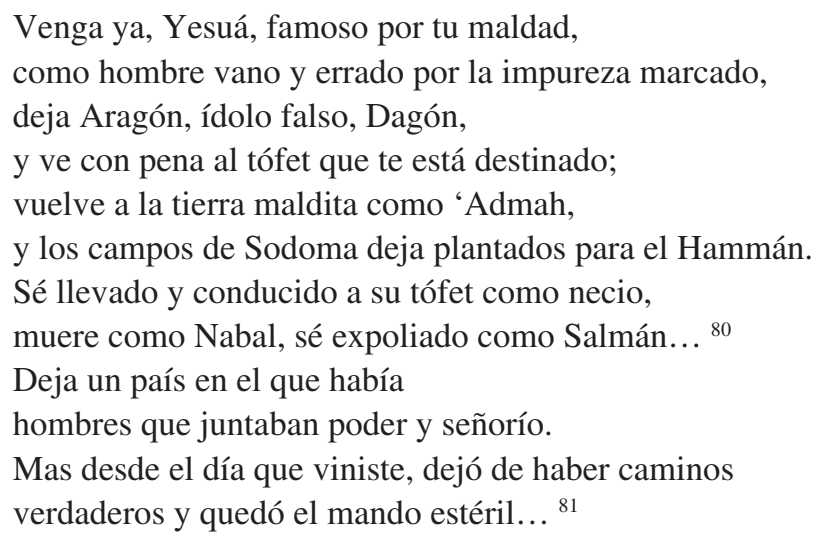

La obsesión de Bonafed por desprestigiar a rabí Jucé llegó a tal extremo, que decidió escribir a sus antiguos amigos de la capital del reino para advertirles del peligro que se cernía sobre ellos por haber aceptado el magisterio del siciliano ${ }^{82}$, al tiempo que redoblaba sus descalificaciones y caricaturizaba las «pretendidas aspiraciones» científicas y poéticas del rabino con duras sátiras, rebosantes de desprecio y resquemor ${ }^{83}$.

De sus poemas se deduce que su forma de entender el judaísmo era muy distinta de la que defendía rabí Jucé, más proclive a algunos rasgos de pietismo

\footnotetext{
${ }^{79}$ SÁenz-Badillos, «Entre Sefarad e Italia», pág. 200.

${ }^{80}$ SÁEnZ-BAdIllos, «Entre Sefarad e Italia», pág. 202.

${ }^{81}$ SÁEnZ-BAdillos, «Entre Sefarad e Italia», pág. 204.

${ }^{82}$ SÁenz-Badillos, «Entre Sefarad e Italia», págs. 203-204.

${ }^{83}$ Refiriéndose a él, llegó a decir que «su lengua es pesada... tartamudea... y emite una especie de susurro». Véase SÁenz-Badillos, «Entre Sefarad e Italia», págs. 203-204, e ID., «Selomoh Bonafed, último», pág. 3.
} 
e incluso de cierto revitalismo religioso (medidas más rigurosas en relación con las normas de pureza y las leyes dietéticas, un nuevo estilo de predicación más centrado en la halajá que en la filosofía...) que nada tenían que ver con la concepción que propugnaba el poeta ${ }^{84}$.

En cuanto a las aptitudes poéticas de rabí Jucé, que, según señala Bonafed en sus textos, rozaban la mediocridad, hay opiniones para todos los gustos. Refiere el propio Bonafed que en 1445, estando él en Belchite, algunos de sus partidarios le escribieron rogándole que compusiera un poema en honor de los judíos que, con sus generosos donativos, habían contribuido a sufragar la adquisición de un nuevo rollo de la Torá para la sinagoga de la aljama de Zaragoza, porque la composición que rabí Jucé había preparado a tal efecto no les había gustado. No sé qué hubo de verdad en todo este asunto, pero lo cierto es que Bonafed aprovechó la ocasión para explayarse a gusto sobre las (desde su punto de vista) ramplonas cualidades poéticas de rabí Jucé.

Quizás convenga señalar que, hasta la fecha, no he encontrado en los protocolos notariales datos sobre Salomón Bonafed. Los hay, aunque no son ni abundantes ni significativos, relativos a rabí Abraham Bonafé, documentado en Zaragoza desde 1405: a raíz de su fallecimiento, en 1428, su viuda Jamila y su hijo Ferrer Bonafé llegaron a un acuerdo con Juan Riera, converso, hermano del difunto y albacea de su sobrino Juanico Riera (hijo de Abraham Bonafé y de Jamila), para repartir la herencia de Abraham ${ }^{85}$. También me consta que en 1450 residía en Tarazona un judío llamado Rubén Bonafed ${ }^{86}$, que bien pudo ser hijo o sobrino de Salomón, puesto que el padre de Salomón (el poeta) también se llamaba Rubén ${ }^{87}$. Esperemos que futuras investigaciones puedan aportar algo más de luz al respecto.

\subsubsection{La credibilidad de Bonafed}

Llegados a este punto, parece oportuno cuestionar la credibilidad de los juicios que Bonafed emitió sobre su contrincante. Cuesta aceptar que rabí Jucé fuese tan nefasto como afirmaba el poeta, máxime cuando -como a continua-

\footnotetext{
${ }^{84}$ Sobre las diatribas lanzadas por Bonafed contra los dirigentes de la aljama zaragozana en torno a 1445, véase el documentado estudio de GUTWIRTH, «Social Criticism», págs. 26-36.

${ }^{85}$ AHPZ, García Gavín, 1428.IX.5, fols. 153r-v.

${ }^{86}$ AHPZ, Miguel Navarro, 1450.II.9, fol. 108.

${ }^{87}$ En 1387 residía en Tortosa el judío Rovén Bonafeu, de esa ciudad. ACA, reg. 1827, fols. $166-166 v$.
} 
ción veremos- las opiniones de los coetáneos sobre su persona son altamente positivas.

Por lo que se refiere a su aspecto físico, preferencias y aficiones, nada se puede alegar a favor o en contra de lo que afirma Bonafed, por falta de pruebas. Asimismo, carecemos de datos que nos permitan pronunciarnos sobre sus pretendidas (por unos) y denostadas (por otros) dotes para la poesía y las ciencias astronómicas ${ }^{88}$.

En cuanto a las acusaciones vertidas por el poeta sobre la capacidad intelectual y la honradez de rabí Jucé, a quien tachaba de «ignorante y farsante»» ${ }^{89}$ amén de una larga retahíla de adjetivos poco amables, sorprende que una persona tan deleznable como la que él describe se ganara la confianza de los dirigentes de la aljama zaragozana y alcanzase el puesto de «Rav» en detrimento de un candidato de la categoría de Bonafed, que estaba vinculado al círculo poético de la aljama de Zaragoza, encabezado por Selomó ben Mesullam de Piera y disuelto tras la llamada Disputa de Tortosa. Y todavía llama más la atención que, al cabo de los años (¡más de quince!), dicho individuo (rabí Jucé) continuara liderando una aljama que, si bien a mediados del siglo xv había experimentado una merma notable desde el punto de vista cuantitativo y cualitativo, seguía siendo la principal del Reino y de la Corona.

Son varios los textos literarios que se refieren al prestigioso rabino, llamado Yosef Yešu'á, que lideraba la comunidad de Zaragoza en la segunda mitad del siglo xv, y es que rabí Yosef Yešu'á no sólo realizó dictámenes halájicos y pronunció homilías, sino que enseñó diversas disciplinas y atrajo a sus clases a numerosos alumnos ${ }^{90}$, algunos de los cuales, que con el paso del tiempo se convirtieron en sabios eminentes, le recordaban con profundo respeto: es el caso de rabí Isaac Aboab (1433-1493), que en sus sermones reprodujo algunas de las enseñanzas recibidas de Yosef Yešu'á ${ }^{91}$.

${ }^{88}$ SÁenZ-Badillos, «Entre Sefarad e Italia», págs. 202-203.

${ }^{89}$ Véase el escrito en prosa rimada de Bonafed contra Jucé Jesuá en Schirmann, «Hapulmus shel Shelomo», págs. 44 y ss., ex Bejarano, «S lomoh ben Reuben Bonafed», págs. 92 (nota 13) y 100. Para una biografía de Salomón Bonafed, véase BEJARANo, «S lomoh ben R éuben Bonafed», págs. 87-102. Véase también GutwirTh, «Social Criticism», págs. 2353; ID., "Leer a Bonafed en su entorno», en La sociedad medieval a través de la literatura hispanojudía, R. Izquierdo Benito y A. Sáenz-Badillos, coords. (Cuenca 1998), págs. 341357, e ID., «Face to Face: History, Phisyognomy and Pictorialism in Solomon Bonafed», en Encuentros y desencuentros, A. Doron, coord. (Tel-Aviv 2000), págs. 327-357.

${ }^{90}$ Así lo reconoce Schirmann en su introducción a «Hapulmus shel Shelomo».

${ }^{91}$ Al que menciona en su Nahar Pison (Zolkiev 1806), 16 b. 


\subsection{Rabí Elías}

Hemos visto que la pugna sostenida en los años cuarenta por el rabinato de Zaragoza no se enterró con Bonafed sino que se reprodujo años después, concretamente en 1454. Aunque en esta ocasión la persona que se enfrentó a rabí Jucé ben Josuá se llamaba Elías.

En los documentos de 1454 no se proporcionan otros datos sobre su identificación, quizás porque se consideraba innecesario. Es de suponer que rabí Elías contaba con el apoyo de una parte de la aljama, seguramente la misma que años atrás se había pronunciado a favor de Salomón Bonafed, ahora fallecido ${ }^{92}$. Se sabe que tres años después (en agosto de 1457) residía en la judería de Zaragoza un rabí llamado «Elía» ${ }^{93}$, pero se desconoce su gentilicio. He rastreado los protocolos notariales coetáneos tratando de descubrirlo, pero hasta la fecha el único rabí llamado Elías, y con apellido confirmado, es Elías Benaroz o Benaroch, que entre 1439 y 1441 estaba domiciliado en Alagón ${ }^{94}$. Esperemos que también en este caso futuras investigaciones contribuyan a concretar su identificación.

\subsection{La aljama o parte contratante}

El tercer protagonista en el documento de 1454 es la aljama de Zaragoza, que figura como contratante. En principio estaba integrada por los varones pecheros mayores de edad, tanto ricos como pobres, pues la penuria económica no era razón determinante para ser excluido de la misma. En cambio, el hecho de gozar de cierta exención tributaria sí implicaba la separación de la comunidad. Tal era el caso de las familias francas Alazar y Caballería, vasallas de la Orden del Hospital, que residían en la judería cerrada, aunque en barrio aparte: estos

\footnotetext{
${ }^{92}$ Según A. Bejarano, su muerte se produjo en 1448 y no en 1445 , como se creía. Véase Bejarano, «S ${ }^{e} l o m o h$ ben Reuben Bonafed», pág. 92.

${ }^{93}$ Habitaba en unas casas que lindaban con las que el judío Perez Caruch había vendido a Gaspar Bonifant. AHPZ, Miguel Navarro, 1457, fols. 326v-327.

${ }^{94}$ La noticia me ha sido facilitada por Susana Lozano. No sé qué relación pudo haber -si acaso la hubo- entre este individuo y el mencionado rabí; lo más seguro es que se trate de dos personas diferentes, porque en enero de 1457 Elías Benarroch, que estaba casado con Jamila de Abencanyas, seguía residiendo en Alagón (AHPZ, Miguel Navarro, 1457, fol. 121). Por esos años (en 1445), tenía su domicilio en Zaragoza un judío llamado Elías que se apellidaba Cohén, pero no me consta que llevara el título de rabí (AHPZ, Miguel Navarro, 1445, fol. 22).
} 
judíos, que constituían la flor y nata de la sociedad judía zaragozana, no emparentaban con los pecheros ni cotizaban con la comunidad; tampoco asistían a las asambleas plenarias, y eso que la mayoría de ellos eran personas cultas y con vocación política. Salvo casos excepcionales, ni siquiera se les convocaba a las reuniones ${ }^{95}$. Por eso no debe sorprendernos su ausencia ni la de otros judíos que también se decían francos (como los Constantiní y Avendahuet), aunque su estatus era diferente.

A la asamblea convocada en 1454 para conocer el contenido de la misiva del infante Juan asistieron cerca de cien individuos cuyos nombres y apellidos han quedado registrados en el acta notarial, junto con sus cargos: allí figuran, en primer lugar, los adelantados y los consejeros, seguidos del clavario, el nuncio o avisador, el rabino y otros miembros de la aljama, bien conocidos por los usuarios de los protocolos notariales de la época. Lo que no sabemos es cuáles fueron las preferencias de cada uno de ellos a la hora de elegir al «Rav», una elección que podía -y solía- provocar enfrentamientos entre los grupos que se disputaban el control de la misma. Parece ser que, años atrás, entre los partidarios de Bonafed estaban los Ben Labí o de la Cavallería ${ }^{96}$, Mosé Abenabez, los Chinillo, los Aninay y la familia Albalag ${ }^{97}$, es decir lo más selecto de la comunidad. Entre sus oponentes, que procedían de las manos media y baja, había judíos pobres, pero también ricos (como los Abnarrabí, el comerciante Mosé Afiá ${ }^{98}$, Mossé Benjamín, Vidal Abulfada, Bonastruc de Salinas, Abraham Soaib ${ }^{99}$ y tantos otros), dotados de cierta influencia y de no poca capacidad de persuasión sobre sus correligionarios de las clases menores. Finalmente, serían estos judíos medianos quienes propondrían y sacarían adelante la candidatura de rabí Jucé en detrimento de Bonafed.

Es justo reconocer que en 1454 rabí Jucé jugó con cierta ventaja sobre rabí Elías, pues, aparte de ocupar el cargo -venía desempeñándolo desde hacía años- de forma interina, contaba con el apoyo del infante Juan que -como se ha dicho- estaba con-

${ }^{95}$ Sobre los Alazar, véase Blasco MARTínez, La judería de Zaragoza en el siglo XIV, págs. 5657, y EAD., «The Expulsion of the Jews from the Lands of the Nobility: The Estates of Caballería and Eleazar and the Order of the Hospitallers» (en hebreo), en Y. T. Assis and Y. Kaplan (eds.), Jews and Conversos at the Time of the Expulsion (Jerusalem 1999), págs.155-175.

${ }^{96}$ Bejarano, «Selomoh ben Reuben Bonafed», pág. 92

${ }^{97}$ Gutwirth, «Leer a Bonafed», pág. 356, e ID., «Social Criticism», pág. 25. Es decir, el círculo de intelectuales que solían reunirse en torno a don Vidal de la Caballería (yerno de don Bienvenist y doña Tolosana de la Caballería), que permaneció fiel a la Ley de sus mayores cuando sus cuñados, tras la llamada Disputa de Tortosa, optaron por el bautismo. Véase BlasCo MARTíneZ, «Mujeres judías zaragozanas ante la muerte», págs. 88-93.

${ }^{98}$ Gutwirth, «Social Criticism», pág. 36.

${ }^{99}$ Sobre todos ellos, ibíd., pág. 37. 
vencido de que lo mejor para todos era que Jucé siguiera siendo «Rav» de la aljama de Zaragoza, no sé si por su actitud menos beligerante que la de Bonafed hacia los conversos, por su ductibilidad o porque -como dice el refrán- más vale malo conocido que bueno por conocer.

\section{CONCLUSIONES}

El presente estudio, además de dar a conocer un documento de contratación de un «Rav» o marbiztorá del reino de Aragón de mediados del siglo xv, ha permitido entender un poco mejor a rabí Jucé ben Josuá: un personaje muy peculiar que, según parece, se enfrentó y derrotó primero al poeta Salomón Bonafed y luego a rabí Elías en la lucha por el rabinato de Zaragoza. Ahora se sabe que no era una figura tan secundaria como se pensaba ${ }^{100}$ ni tan nefasta como quiso hacernos creer su rival, que se autoproclamó el mejor intelectual y poeta de su tiempo ${ }^{101}$ y el líder religioso indiscutible de la aljama zaragozana. Parece ser que, a la larga, esa arrogancia le propició a Bonafed más enemigos que otra cosa y que su excesiva prepotencia le pasó factura, pues los judíos zaragozanos, en su mayoría artesanos, prefirieron como «Rav» a un personaje menos laureado pero más comprensivo y cercano. Es evidente que rabí Jucé ben Josuá tenía cualidades suficientes para ejercer el rabinato en Zaragoza, tarea que desempeñó durante más de quince años consecutivos, gracias al respaldo del monarca Juan II y de parte de la aljama, pero también a su buen hacer.

${ }^{100}$ SÁEnZ-Badillos, «Entre Sefarad e Italia», pág. 199.

${ }^{101}$ Y seguramente lo era, pues poseía una sólida formación: se sabe que estudió Lógica (en latín) con un maestro cristiano A. SÁenz-Badillos y A. Prats Oliván, «Selomoh Bonafed y la lógica cristiana del siglo XV», Revista Española de Filosofía Medieval, 10 (2003), págs. 15-27. 


\section{ApÉNDICE DOCUMENTAL ${ }^{102}$}

[Zaragoza, 1 de agosto de 1454]

\section{$/ /{ }^{613}$ Carta de la firma del Rau.}

Sia a todos manifiesto, que plegada et ajustada la aliama de jodios de la ciudat de Caragoca en la sinoga mayor /de la dita aliama/ por mandamiento de don Miguel d.Aliaga, lugartenient por el muy honorable don Johan Royz, jurista, consellero del senyor Rey et merino de la ciudat de Caragoca, et de los adelantados dius nonbrados por voz et crida de Acach Zayet, jodio, nuncio et coredor [sic] publico de la dita aliama, el qual fizo relacion a mi notario infrascripto, presentes los testimonios diuso nonbrados, hauer clamado la dita aliama pora la ora et lugar infra scriptos. Et plegados et ajustados en la dita sinoga do otras vegadas son costunbrados plegar et ajustarse por fazer et espachar los fechos de la dita aliama, en la qual dita sinoga et congregacion de la dita aliama fueron presentes los qui se siguen:

Primerament /nos/ Simuel Velnopiel [sic], adelantado, Juce Benabez, lugartenient de Bonafos Abnarabi, et Salamon Alixuili lugartenient de Jaco Galaf, adelantados /de la dita aliama/; Gento Leui, Simuel Jaba, Dauit Vitales, Mosse Benceui, Gento de Corti, Simuel Rampnat, Jaco Nazir ${ }^{103}$, Mosse Aninay lugartenient de Simuel Addich ${ }^{104}$, Jaco Auiayu lugartenient de Gento Cabez, /Mordehay Amariello lugartenient de Jaco Senyor ${ }^{105}$ /, conselleros de la dita aliama; maestre Juce Orabuena, Mosse Afia, Azmel Abnarrabi, Abram Abiayu, Jesuas Benjamin, //613v Abram Benpesat, Juce Benardut, Crescas Abnarabi, Vidal Abnarrabi, Sento Algranati, Leon Mascaran, Acah Auayu, Bienuenist Alpastam, rabi Juce Cahadias, Juce Algranati, Simuel Falleua ${ }^{106}$,

${ }^{102}$ En la transcripción del documento inserto a continuación, he procurado ceñirme al original lo más posible, respetando la ausencia de cedilla cuando no la hay (Caragoca, Ribagorca...) y el uso de $\mathrm{i} / \mathrm{j}$ y de $\mathrm{u} / \mathrm{v}$ (vniuersidat...), porque no dificulta la lectura del mismo y puede facilitar a los filólogos su uso en futuras investigaciones; en cambio, la doble letra $\mathrm{r}$ y f inicial se ha asimilado en una sola. La elisión de una vocal por contracción se expresa mediante un punto (d.Aragón). Para agilizar la comprensión del texto, tanto el uso de mayúsculas como los signos de puntuación responden a las exigencias actuales. He optado por incluir en notas a pie de página lo que está tachado, pues considero que, pese a la dificultad que en ocasiones presenta su transcripción, puede ayudar a entender la forma en que se redactó el documento y las vacilaciones que el notario cristiano experimentó al tener que expresar conceptos hebreos en lengua romance. Los interlineados van incluidos entre barras (/.../), mientras que el comienzo de folio (recto y vuelto) se indica con un número sobrepuesto tras doble barra (//).

${ }^{103}$ Tachado: conselleros.

${ }^{104}$ Tachado: de Jaco Senyor.

${ }^{105}$ Tachado: conselleros

${ }^{106}$ Tachado: Acach Faleua. 
Acach Abullaten, Tuui Benlopiel, Salamon Gallur, Mosse Nageres, Jaco Abella, Mosse Abullamin, rabi Jaco Darsan, Jaco Çarruch, Juce Benardut menor, Simuel Benatan, Juce Zayet, Habram Abuzmel, Acach Alcolumbre, Jaco Amato, Acach Cohen curacero, Juce Pati, Juce Benarrama, Vidal Abulfada, Simuel Abayut, Alazar Gallur, Juce Moreno, Perez Carruch, Juce Larabica, Jaco Benbitas, Habram Valat, Dauid Azcarriel, Salamon Abullacen, Alazar Carfati, Acach Falaquera, Sento Aguelo, Acach Alcastiel, Jeuda Capacho, Abram Abencanyas, Gento Baco, Simuel Carfati, /Juce/ Abayut, Jeuda Abenbitas, Juce Benargaz, Abram Nagares, Leon Bilforat, Abram Leui, Jeuda Zunana, Simuel Pati, Salamon Canas, Jaco Çalama, Junez Canphi, Junez ${ }^{107}$ Abiau, Jaco Fichel, Mosse Amato, Abram Carfati, Mosse Cides, Juce Abotayo, Acach Acafar, Haym ${ }^{108}$ Farhi, Gento Cucuf, Jaco Darsan, Mosse Chamorro, Jeuda Algranati, Juce Eli, Jeuda Trigo, Jaco Avendada, Aron Far, Acach ${ }^{109}$ Morfayim, Mosse Alballi, Juce Capacho, Abram de Salinas, Simuel Piquo, Salamon [Ard]it, Abram Ardit, Jeuda Benardut, Acach Fichel et Mosse Abella. Et desi todos los jodios de la dita aliama plegados en la dita sinoga, aliamantes et aliama fazientes, ${ }^{614} / /$ et assi stando plegados /nos los/ ${ }^{110}$ sobreditos /et seyendo present en la dita placa el Rau rabi Jucen Benjossua/, como por el dito lugartenient de Merino ${ }^{111}$ fuesse proposado que por vn correu hauia seydo a el dada una letra patent del senyor Rey de Nauarra, lugartenient general del senyor Rey, en paper scripta et con su siello sillada, et ${ }^{112}$ el dito correu le hauies dito, de part del dito senyor Rey lugartenient, que aquella deuiesse presentar a la dita aliama et aquella el dito lugartenient hauiesse et haya presentado ${ }^{113}$ a uos ditos adelantados ${ }^{114}$, conselleros et aliama de la part de suso nonbrados, la qual es del tenor siguient:

Don Johan, por la gracia de Dios Rey de Nauarra, Infant et Gouernador general d.Aragon e de Sicialia [sic], Duch de Nemos, de Monblanch e [sic] de Penyafiel, Compte de Ribagorca et Senyor de la ciudat de Balaguer, lugartenient general del serenissimo senyor Rey, hermano nostro muy honrrado, a los delantados [sic], clauario et otros oficiales, aliama et vniuersidat de jodios de la ciudat de Caragoca e singulares de aquella, la suya gracia. Nos somos informados cunple mucho a la honrra he beneficio de aquexa dita aliama, la qual es muy singular en el regno de Aragon, que rabi Juce Benjosua, judio, sia Rau de aquella assi como muy abto e suficient al dito oficio de Rau, el qual no

\footnotetext{
${ }^{107}$ Tachado: Abram.

${ }^{108}$ Tachado: Fayi.

${ }^{109}$ Tachado: Mordohay.

${ }^{110}$ Tachado: los.

${ }^{111}$ Tachado: fue.

${ }^{112}$ Tachado: dixole.

${ }^{113}$ Tachado: segunt que presento a vos.

${ }^{114}$ Tachado: et.
} 
solament basta e es suficient $/ /^{614 \mathrm{v}}$ a lo que por el dito su oficio ha e tiene cargo et [sic] deue fazer en la dita aliama de Caragoca, mas enquara aquel poran recorrer, consultar et prender consello las otras aliamas de judios del dito Regno, en las quales no ha suficiencia de Raus, porque precedient la dita informacion, e hauida sobre aquella deliberacion, proueymos, dezimos e mandamos a vosotros e a cadauno de uos, dius incorrimiento de la yra e indignacion del senyor Rey encura e[n] pena de mil florines d.oro d.Aragon de los bienes de vosotros qui el contrario fara hauedores e a los cofres del dito senyor Rey aplicaderos, que de continent, vista la present, sin consulta alguna, al dito rabi Juce Benjosua Rau condugades et pensionedes a seruir aquexa dita aljama de Caragoca del dito oficio por tienpo de diez anyos primero venidores et con el salario e en la manera que lo haueys tenido, conduzido o pensionado en estos cinquo anyos mas cerqua pasados e no condugades ni salariedes otro rabi alguno en la dita aliama durant aqueste dito tiempo quel dito rabi Juce seruira, como segunt la dita informacion quende hauemos aqueste sia por si a solas suficient e baste a seruir toda la dita aliama e muyto $615 / /$ mayor en el dito oficio de Rau. E aquesto por tal que la dita aljama no sia uexada de salarios, spensas inutiles o al menos no necesarias. Mandantes por aquesta messma a los ditos adelantados qui agora sodes e a los qui por tienpo seran de la dita aliama, dius las penas suso ditas, que pongades e pongan en el capbreu que daredes e daran al clauario de la dita aliama la pension que cada un anyo se deura dar e pagar al dito rabi Jucen, Rau, en las tandas que se ha acostunbrado pagar e que aquellas le sian dadas e pagadas sin dilacion alguna. $\mathrm{E}$ todo lo sobredito queremos e mandamos por vosotros seyer inuiolablement obseruado, exseguido e feyto segunt que de suso se contiene, qualesquiere deferencias, altercaciones, questiones, causas e pleytos siquiere actos que entre el dito rabi Jucen de la ${ }^{115}$ una part et el rabi Elias, judio, de la otra part o entre vosotros o qualesquiere singulares de la dita aliama sian stadas, succitadas, /mouidas/ o prendan por razon de conduzir e salariar al dito rabi Jucen et al dito rabi Elias e encara qualesquiere letras e prouissiones nuestras atorgadas por aquesta razon de sobreseymiento de no proceyr en las ditas diferencias, alterquaciones, questiones, causas e pleytos e actos fasta que nos fuessemos $/ /{ }^{615 \mathrm{v}}$ personalment en Caragoca directas a vosotros et al dito rabi Jucen et encara al lugartenient de Merino de la dita ciudat de Caragoca, en res no contrastantes e no obstantes enquara qualesquiere regimiento, enprendimientos et ordinaciones de la dita aliama con aladma o penas a lo susodito e alguna cosa contrastantes; las quales nos, quanto a empachar lo sobredito pudiessen en algo fazer contra el rabi Juce Benjosua, tiramos e suspendemos, romanientes empero aquellas en todo lo otro en su plena firmeza e valor. Mandantes por aquesta messma al Merino e lugartenient de Merino de la dita ciudat de Caragoca que si non faredes compliredes [sic] las cosas suso dichas, segunt que por nos de suso son scriptas e mandadas, e no daredes e pagaredes o no daran et pagaran al dicho rabi Jucen

\footnotetext{
${ }^{115}$ Tachado: otra.
} 
lo que por razon del dito su oficio de Rau tro aqui le es deuido e de aqui avant se le deura, segunt vna prouission que en aquesta razon por nos le fue atorgada, e contra aquella et aquesta en alguna manera faredes o veniredes, faran o vendran, que por las penas suso dichas que por la dita razon hauredes e hauran encorrido fagan rigida execucion et conpulsa en bienes vuestros e suyos e de cadauno de uos e de aquellos, ensenble con qualesquiere missiones e danyos por razon de las ditas execuciones justament $/ / 616$ fazederas, como nos por beneficio de la dita aliama en tal caso queremos e mandamos que asin se faga. E guardar vos de fazer el contrario en alguna manera si deseades al dicho senyor Rey e a nos seruir e complazer e las suso ditas penas euitar. Dada en la ciudat de Jaqua, a xxv dias de julio en el anyo de la Natiuidat de nuestro Senyor mil quatrozientos cinquanta y quatro. El rey Johan. In Itinerum locumtenentie, quarto. Vidit Pascasius de Moros, locumtenens thesaurarii. Vidit Jacobus Pastor proconseruatore Aragonum. Vidit Anthonius Sanchez.

Et assi presentada la dita letra, el dito luguartenient [sic] de Merino nos ${ }^{116}$ hauiesse /et haya/ requerido que exsiguiesemos lo contenido en aquella, en otra manera que ${ }^{117}$ tenia mandamiento del dito senyor Rey lugartenient que por las penas en aquella puestas e contenidas fiziesse regada execucion en los bienes de los contrafazientes et ${ }^{118}$ hauiesse requerido, segunt que requirio de todas e cadaunas cosas sobreditas por el notario infrascripto seyer ${ }^{119} /$ l.ende/ feyta carta publica. /Et/ nos ditos adelantados /et aliama/ de suso nonbrados, respondiendo a lo sobredito, hauiessemos respuesto e dito que la dita letra recibiamos con humil subieccion et reuerencia del dito senyor Rey lugartenient.

Et por quanto por algunos de los congregados en la dita ${ }^{120}$ plaça hauia seydo mouido que, atendido quel dito senyor Rey nos mandaua firmar a vos //616v dito rabi Jucen ben Josua ${ }^{121}$ /por Rau siquiere Marbiztora/ de la dita aliama por /tiempo/ [de] diez anyos, et la dita aliama hauiessen feyto cierta ordinacion con alatma et niduy que no pudiessen pensionar ${ }^{122}$ ningun Rau o rabi sin consentimiento /de todos/ ${ }^{123}$ los adelantados e de los del consello de la /dita aliama et de quantas/ ${ }^{124}$

\footnotetext{
${ }^{116}$ Tachado: los.

${ }^{117}$ Tachado: tuuiesse.

${ }^{118}$ Tachado: requiriesses.

${ }^{119}$ Tachado: ne.

${ }^{120}$ Tachado: otra.

${ }^{121}$ Tachado: que rabi.

122 Tachado: rabi.

${ }^{123}$ Tachado: de.

${ }^{124}$ Tachado: consello et de LXxx.
} 
personas fuera de consello /a conplimiento ento de huytanta personas/, por tanto que les parescia, pues el /dito/ senyor Rey dispensaua en las penas de la dita ordinacion, que ${ }^{125}$ /nos ditos adelantados et/aliama, de voluntat de vos, dito rabi Jucen ${ }^{126}$, deuiamos soltar la dita pena de alatma e niduy. Por tanto nos, todos los de suso nombrados, aliamantes e aliama fazientes et representantes ${ }^{127}$, todos concordes, /las penas de la dita/ ordinacion, de voluntat e consello de vos dito rabi/Jucen/ e juxta tenor de la dita letra del dito senyor Rey lugartenient ${ }^{128}$, soltamos e suspendemos e queremos a las tales infrascriptas no contrastar ni obstar. Et yo, dito rabi Jucen suelto, tiro ${ }^{129}$ la dita aladma e niduy tanto quanto el dito senyor Rey dispensa en aquella por la dita et preinserta letra desuso presentada. Et con aquesto, nos ditos adelantados e aliama ${ }^{130}$ aliamantes et aliama fazientes e representantes, en virtut de la dita e preinserta letra del dito senyor Rey de Nauarra lugartenient ${ }^{131} \mathrm{e}$ del mandamiento por aquella a nos feyto por el dito senyor Rey lugartenient, firmamos et conduzimos por Rau siquiere ${ }^{132}$ Marbiztora a vos, dito rabi Juce Beniossua, //617 por tiempo de diez anyos contaderos del ${ }^{133}$ primero dia del mes de setiembre primero vinient adelant e con las cargas e condiciones infrascriptas, e constituymos vos de pension en cadaun anyo durant el dito tiempo de los diez anyos primero vinientes e continuos ochocientos sueldos dineros jaqueses buena moneda corrible en el regno de Aragon ${ }^{134}$, los ditos ochocientos solidos del dito salario e nouanta solidos del loguero de la casa en cadaun anyo, a vos dito rabi Jucen en tres terças siquiere tandas anuales et antecipados, es asaber ${ }^{135}$ dozientos nouanta seys solidos ocho dineros del principio del anyo, que es el primero dia de setiembre ${ }^{136}$, et otros CCLXXXXVI solidos VIII dineros antecipados en el principio del tercio segundo del dito anyo, que es el primero dia de janero, e otros dozientos nouanta seys solidos dineros /VIII dineros/ antecipados en el principio del tercio tercero del anyo, que es el primero dia de mayo.

\footnotetext{
${ }^{125}$ Tachado: la dita.

${ }^{126}$ Tachado: deuiaes nos tirar.

${ }^{127}$ Tachado: las penas de la.

${ }^{128}$ Tachado: tiramos.

${ }^{129}$ Tachado: et de feyto el rabi Jucen solto la dita alatma et niduy.

${ }^{130}$ Tachado: alma.

${ }^{131}$ Tachado: e de mandamiento por aquellos ditos feyto e por no emdar ni incurrir en las penas en aquella contenidas.

${ }^{132}$ Tachado: requiridor ley.

${ }^{133}$ Tachado: present et infrascripto dia.

${ }^{134}$ Lo que sigue hasta el punto ad marg. inferior.

135 Tachado: los.

${ }^{136}$ Tachado: agosto.
} 
Item vos prometemos dar e pagar en cada un anyo durant el dito tiempo pora ayuda del loguero de la casa do vos habitaredes nouanta solidos jaqueses [ad marg. inferior: de mano del clavario qui sera de la dita aliama].

Item vos damos facultat e licencia e bastant poder que en cadaun anyo durantes los ditos diez anyos podades liberament e franca, sin incorrimiento de pena alguna, conprar, meter e fer meter et encubar en casa vuestra o en aquel lugar que a vos plazera ocho cargas de huuas /de las costumbradas en la ciudat de Caragoca/, pesantes cada carga setze pessas, para que de aquellas podades fazer et ${ }^{137}$ fer fazer vino pora /vos et pora/ prouission vuestra e de los de vuestra casa e para todos los que conbran a vuestra taula e pora los moços ${ }^{138}$ vuestros e seruiciales, e a los entradores e sallidores de casa vuestra, asi quel vino malluelo e /todos los/ redemalluelos que saldran de las ditas ocho cargas de ${ }^{139}$ huuas francas de sisa de vino de la acostumbrada pagar en la dita aliama, ara se arriende la sisa del vino a la plana ara se arriende a gabella.

Item es condicion que nos, ditos adelantados et aliama e los adelantados et aliama qui por tenpo [sic] seran durant $/ /{ }^{617 \mathrm{v}}$ el dito tiempo de los ditos diez anyos, sian tenidos e deuan arrendar la dita sisa del vino, ara arrienden a la plana ara a gabella et a qualquiere persona de qualquiere ley o condicion sia con capitol expreso, que vos dito rabi Jucen Benjosua podayes meter o fer meter pora prouision de vino de vuestra casa e pora vuestros moços e moças e companya /et a todos los comedores de vuestra taula et entradores et sallidores de vuestra casa/ las ditas ocho cargas de huuas, e que no siades tenido manifestar ni pagar cosa alguna por sisa del dito vino a persona alguna, ara la dita sisa se arriende a la plana ara la dita sisa ${ }^{140}$ se arriende a gabella, ni arrendador ni sisero ni gabellador present, pasado o venidor de qualquiere ley ${ }^{141}$, preheminencia o condicion sian, asi de mosto, malluelo /et de todos los/ redemalluelos ni de ${ }^{142}$ cosa otra alguna que sallira de las ditas gueyto cargas de huuas.

Item es condicion que durant el dito tiempo de los ditos diez anyos vos dito rabi Jucen siades franquo de todos e qualesquiere peytas, tallas, cargas, gitas, vasallages o demandas del regno d.Aragon e de la ciudat de Caragoca e de la dita aliama e de la obra e guarda de los muros de la dita ciudat e de la guarda de la Aliaferia del senyor Rey, de la dita ciudat e de qualesquiere otras gitas e cargas ordinarias et extraordinarias que son o puedan seyer inposadas durant el dito tiempo sobre la dita aliama.

\footnotetext{
${ }^{137}$ Tachado: fagades.

${ }^{138}$ Tachado: de vos.

${ }^{139}$ Tachado: uuas.

${ }^{140}$ Tachado: ara.

${ }^{141}$ Tachado: present ciencia.

${ }^{142}$ Tachado: cosa otra.
} 
Item es condicion que vos dito rabi Jucen siades tenido sermonar publicament en la sinoga mayor de la dita ciudat //618 de Caraguoca [sic] o en qualquiere otra sinoga o midras do se plegara la dita aliama hun sermon en cadahun ${ }^{143}$ mes durant el dito tiempo de los ditos diez anyos, en qualquiere dia /de/ sabado o de fiesta que vos querredes; e si por ventura faltareyes por alguna causa o necessidat de fazer algun mes el dito sermon, que siades tenido ${ }^{144}$ emendar lo en otro mes; e si por ventura en hun mes faredes dos sermones, que vos sia el vno recebido en conto ${ }^{145}$ de otro mes, en tal manera que no siades obligado de fazer mas de dotze sermones cada anyo.

Item que siades tenido e obligado de demostrar ley publicament en vuestro studio ${ }^{146}$ todo tiempo que vernan a vos ninyos a requirir a nuestro senyor en esta manera, que en cada semana continuo en los ${ }^{147}$ tres dias primeros, es asaber en el tiempo del verano /de dia/ et en el tiempo del yuierno en las nueytes, siades tenido declarar una licion del Talmut, la que vos querredes; et en los tres dias çagueros, en el tiempo del verano de ${ }^{148}$ dia et en el tiempo del yuierno de nueytes, et en los sabados que no haura sermon ni ningun storbo otro ${ }^{149}$, es asaber en los sabados en la manyana antes de oracion /de la manyana/ et en la tarde antes de oracion de las viespras, siades tenido declarar les hun troz razonable de las Profecias e de las Declaraciones, aquel que vos querredes, a todos los que vendran $/ /{ }^{618 v}$ a vuestro studio.

Item que no podades amostrar a ninguno sciencia alguna forana por via de firmeza en los ditos tiempos d.aqui a que ayades declarado la licion o troz razonable de las ditas Profecias que vos querredes declarar e leyr en cadauno dellos ditos dias. Empero si en los ditos dias o alguno dellos erades occupado de algun enpacho o necessidat por los quales no pudiessedes leyr, que en los dias que seredes ocupado no siades tenido mostrar la ley segunt dito es, conque en los dias en que auredes el dito storbo o necessidat no podades ${ }^{150}$ mostrar a ningun diciplo vuestro ninguna sciencia forana por via de firmeza.

Item que siades tenido sermonar publicament a la dita aliama, tod.ora que sera necesario o querra la dita aliama que fagades sermon, sobre qualquiere cosa que ${ }^{151}$ con-

\footnotetext{
${ }^{143}$ Tachado: dia.

${ }^{144}$ Tachado: fazer en el mes que vendra apres del que no hauredes fecho sermon, fazer dos sermones.

${ }^{145}$ Tachado: del mes que apres de aquel, en el qual haueran feyto dos sermones.

${ }^{146}$ Tachado: studio.

${ }^{147}$ Tachado: quatro.

${ }^{148}$ Tachado: ora.

${ }^{149}$ Tachado: uno.

${ }^{150}$ Tachado: mo.

${ }^{151}$ Tachado: ordenaran.
} 
cordaran los adelantados que son o seran de la dita aliama e vos diran que sermoneyes, empero que sian tenidos fazer vos lo dezir o intimar quatro dias ante que no hayades a sermonar, excepto que tod.ora que ordenaran deuades sermonar sobre muert de qualquiere singular de la dita aliama que durant el dito tiempo ${ }^{152}$ finara, que siades tenido sermonar tod.ora que sera necessidat por muert de qualquiere singular de la dita aliama, faziendo uos lo asaber /antes/ con tiempo //619 razonable a conoxienca de los ditos adelantados.

Item que siades tenido durant el dito tiempo de los ditos diez anyos ordenar a la dita aliama qualesquiere cartas o letras de rectorica tod.ora que los ditos adelantados de la dita aliama /concordaran et/ vos lo diran et ${ }^{153}$ dando /vos/ ${ }^{154}$ tiempo razonable.

Item que siades tenido consellar a los berolins de la dita aliama e deliberar e screuir les todas las pronunciaciones e sentencias que se daran e seran necessarias pronunciar e fazer durant el dito tiempo en qualesquiere processos e causas que se leuaran deuant los ditos berolins, segunt ley e segunt lo que ${ }^{155}$ abasta vuestro saber e dando vos tiempo razonable.

Item es condicion que durant el dito tiempo ${ }^{156}$ vos dito rabi Jucen no podades mudar vuestra morada et habitacion ni partir de la present ciudat de Caraguoca si ya no era por alguna necessidat et que /la/ absencia fuesse por poco tiempo, empero que durant la dita ${ }^{157}$ necesidat podades yr doquiere que necessario sera fuera de la dita ciudat sin demandar ni hauer licencia de los adelantados de la dita aliama ni de otra persona alguna.

Item es condicion que en casso $/ /{ }^{619 v}$ que, lo que Dios no quiera, contescera durant el dito tiempo de los ditos diez anyos en la dita ciudat hauer pestilencia de muertes /siquiere mortalera/, que en el dito caso podades sallir de la dita /ciudat/ vos e toda vuestra companya sin licencia de los ditos adelantados ni de otra persona alguna e podades hir ${ }^{158}$ et habitar et star al lugar do vos querredes e podades star et habitar con toda vuestra conpanya fuera de la dita ciudat tanto quanto durara la dita pestilencia /siquiere mortalera/ e no mas.

Item es condicion que vos, dito rabi Jucen, durant el dito tiempo no podades excomunicar/ni/ denunciar por excomunicando a ningun judio ni judia de la dita aliama si ya no era con licencia e voluntat de los adelantados e berolins de la dita aliama.

\footnotetext{
${ }^{152}$ Tachado: sermona.

${ }^{153}$ Tachado: ordenaran.

${ }^{154}$ Tachado: les.

${ }^{155}$ Tachado: abosta.

${ }^{156}$ Tachado: por.

${ }^{157}$ Tachado: anescesidat pueda.

${ }^{158}$ Tachado: et.
} 
E con las ditas condiciones e pactos nos, ditos adelantados et aliama, firmamos e conduzimos a vos dito rabi Jucen por Rau siquiere ${ }^{159}$ Marbiztora de la ley durant el dito tiempo de los ditos diez anyos. Et prometemos, conuenimos e nos obligamos en monbre [sic] et voz de la dita aliama a vos dito rabi Jucen que vos dito rabi Jucen faziendo, seruando e compliendo todas et cadaunas cosas sobreditas e que en virtut de la sobredita e present carta $/ / 620$ sodes tenido tener, seruar e fazer, vos daremos e pagaremos nos, ditos adelantados e aliama e los adelantados e aliama que durant el dito tiempo seran vos daran e pagaran, los ditos ochocientos sueldos del sobredito vuestro salario siquiere pension ${ }^{160}$ et nouanta sueldos poral dito loguero de la casa do vos habitaredes, et vos tendremos, conpliremos, guardaremos et seruaremos, tendran e seruaran e conpliran, todas e cadaunas cosas sobreditas. Et que en virtut de la present carta nos, ditos adelantados et aliama, somos tenidos tener e conplir, seruar e guardar e que contra aquellas ni alguna dellas no faremos, vendremos ni consintremos seyer feyto ni faran, vendran ni consintran por alguna causa, dreyto, manera o razon. Et encara en nonbre e voz de toda la dita aliama nos obligamos de mantener vos e conservar a vos todas las cosas de suso ditas e de tirar de sobre vos todo contrastador et enpachador que en las sobreditas cosas o alguna dellas vos pendra contrast o empacho. Et si por fazer a nos, ditos adelantados et aliama e singulares de aquella et a los adelantados, aliama, singulares de aquella qui durant el dito tiempo seran, todas e cadaunas cosas anteditas et en la present carta contenidas que nos ditos adelantados et aliama somos tenidos e deuemos tener, seruar, guardar e conplir a vos, dito rabi Jucen, conuendra fazer expensas, danyos, interesses e menoscabos sustener en qualquiere manera, todos aquellos et aquellas vos prometemos e nos obligamos pagar, $/ /^{620 v}$ satisfer et emendar conplidament; de los quales e de las quales queremos, atorgamos et expresament consentimos que vos, dito rabi Jucen, ende siades creydo por vuestra simple palaura sines testimonios, jura e toda otra manera de probacion requerida; e por todas e cadaunas cosas sobreditas ${ }^{161}$ tener e conplir, obligamos a vos, dito rabi Jucen, todos los bienes e rendas de la dita aliama, si mobles como sedientes, haudos e por hauer en todo luguar; e renunciamos en las sobreditas cosas a nuestro judge e judicio ordinario e local et el judicio de aquel, e diusmetemos a nos et a la dita aliama e singulares de aquella por la dita racon a la jurisdiccion, cognicion, execucion e conpulsa del senyor Rey, Gouernador rigient el oficio de aquel, Justicia de Aragon, Merino de Caragoca e de qualesquiere otros judges et oficiales ante quien por la dita razon, a nos e a la dita aliama conuenra querredes, e deuant de los quales e cadauno dellos e de los lugarestenientes dellos e de cadauno dellos vos prometemos e nos obligamos pagar, responder e fazer conplimiento de dreyto e de justicia. Et renunciamos

\footnotetext{
${ }^{159}$ Tachado: requeridor.

${ }^{160}$ Tachado: cinquanta.

${ }^{161}$ Tachado: dener.
} 
en las sobreditas cosas a todas e cadaunas defensiones, excepciones, beneficios et allegaciones ${ }^{162}$ de dreyto, ritu, tecanas et vso e consuetud de jodios a las sobreditas cosas o alguna dellas repugnantes; e por mayor firmeza e seguredat de las anteditas cosas nos, ditos adelantados e todos los otros desuso nombrados, aliamantes et aliama fazientes e representantes, en nombre e voz de la dita aliama prendemos quinyan en poder de Abram Muriel e Sento Cohen, jodios, testimonios de la part de yuso nombrados, segunt ley de jodios, de tener, seruar, guardar e conplir todas e cadaunas cosas sobreditas, e que nos e la dita aliama somos tenidos e deuemos tener, seruar, guardar e conplir, e que contra aquellas ni alguna dellas no $/ /{ }^{621}$ faremos, vendremos ni consintremos seyer feyto por alguna causa, dreyto, manera o razon.

E yo dito rabi Jucen Benjossua, acceptando la dita firma siquiere conduccion fecha por vos ditos adelantados et aliama, de mi dito rabi Jucen pora Rau siquiere ${ }^{163}$ Marbiztora por el dito tiempo de los ditos diez anyos e por el precio de los ditos ochocientos solidos et pora ayuda del loguero de la casa do yo deuo morar nouanta solidos, pagaderos en cadaun anyo durant el dito tiempo en los terminos e tandas sobreditas, /et por la dita franqueza de sisa de ocho cargas de huuas en cadanyo/ e con las condiciones ${ }^{164}$ sobreditas, las quales aqui he et hauer quiero por ditas, repetidas e reyteradas bien assi como si por mi fuessen aqui otra vegada ditas, repetidas e reyteradas, las quales todas e cadauna dellas tanto quanto a mi se sguardan, prometo, conuiengo e me obligo a vos ditos adelantados et aliama tener ${ }^{165}$, conplir, seruar e guardar e contra aquellas ni alguna dellas no fazer venir ni consentir seyer feyto por alguna causa, dreyto, manera o razon. E si por fazer me tener, seruar e conplir todas e cadaunas cosas sobreditas et en la present carta contenidas e que yo so tenido e deuo tener, seruar e conplir a vos, ditos adelantados et aliama qui de present soys et a los adelantados et aliama qui seran durant el dito tiempo conuendra fazer expensas, danyos, interesses e menoscabos sustener en qualquiere manera, todos aquellos et aquellas vos prometo, conuiengo e me obligo conplidament pagar, satisfer et emendar; de los quales e de las quales quiero, atorgo et expresament consiento que vos, ditos adelantados et aliama et los adelantados et aliama qui ${ }^{166}$ durant el dito tiempo ende siades et sian creydos por vuestra et suyas sinples palauras, sines testimonios, jura e toda otra manera de probacion requerida. E por todas e cadaunas cosas sobreditas tener e conplir //621v obligo a vos, ditos adelantados et aliama, todos mis bienes asi mobles como sedientes hauidos e por hauer en todo lugar, et renuncio en las sobreditas cosas a mi judge ordinario e local et el judicio de aquel, e prometo e me

\footnotetext{
${ }^{162}$ Tachado: asi.

${ }^{163}$ Tachado: requeridor de la ley.

${ }^{164}$ Tachado: e cartas.

165 Tachado: complir.

${ }^{166}$ Tachado: seran.
} 
obligo por la dita razon fazer vos complimiento de dreyto e de justicia deuant los sobreditos senyores judges et oficiales et de los lugarestenientes dellos et cadauno dellos, et renuncio en las sobreditas cosas a todas e cadaunas excepciones, beneficios, allegaciones e defensiones de dreyto, ley, ritu, tecanas, vso et consuetut de judios a las sobreditas cosas o alguna dellas repugnantes; et por mayor firmeza e seguredat de ${ }^{167}$ todo lo sobredito, yo dito rabi Jucen Benjossua ${ }^{168}$ prengo quinyan segunt ley de jodios em poder de Sento Cohen, jodio testimonio de yuso nombrado ${ }^{169}$, a entencion del Creador e de la dita aliama de no partir mi morada ni mi staia, departimiento ni staia de firme en todo el dito tiempo de la sobredita aliama, sino segunt es dito asuso, cessant todo genyo et art ni puerta de soltaria o sbaratamiento alguno al mundo.

Et encara juro por los diez Mandamientos de la ley de Moysen por mis manos corporalment tocados, en poder de Sento Cohen, testimonio diuso nombrado, a entencion del Creador e de la dita aliama ${ }^{170}$, que durant los ditos diez anyos no mudare mi morada e habitacion de la dita aliama, mudamiento de firmeza et habitacion de durada, sino segunt dito es asuso, cessant todo genyo et art ni puerta de soltaria o sbaratamiento alguno al mundo, segunt de suso dito es.

Feyto fue aquesto en la ciudat de Caragoca el primero dia del mes de agosto anno a natiuitate Domini millesimo quadrin-// $/ 22$-gentesimo quinquagessimo quarto, presentes testimonios fueron a las sobreditas cosas: el discreto Johan de Barachina, notario, ciudadano de la dita ciudat; Johan Moreno, vezino ${ }^{171}$, e Sento Cohen et Abraham Moriel, jodios, habitantes ${ }^{172}$ en aquella.

[AHPZ, Miguel Navarro, 1454, fols. 613-622]

${ }^{167}$ Tachado: todas e cadaunas cosas anteditas.

${ }^{168}$ Tachado: prometo e juro por los diez mandamientos de la ley de Moysen por mis manos corporalment tocados et.

${ }^{169}$ Tachado: de tener, seruar, complir e guardar todas e cadaunas cosas sobreditas que yo encorri de la sobredita present carta de no tener, seruar e conplir e guardar e de no fazer, venir ni consentir seyer feyto contra aquellas ni alguna dellas por alguna causa, dreyto, manera o razon dius pena de perjurio et ins...

${ }^{170}$ Tachado: de sera.

171 Tachado: de la dita ciudat.

172 Tachado: en la dita ciudat. 


\section{RESUMEN}

La renovación en el cargo de «Rav» o marbiztorá de la aljama de judíos de Zaragoza a mediados del siglo XV generó una situación conflictiva entre los aspirantes al puesto (rabí Jucé ben Josuá y rabí Elías) y sus partidarios. Finalmente se resolvió favorablemente para el primero de ellos, que contó con el apoyo del infante Juan, lugarteniente del rey de Aragón. La documentación conservada en el Archivo notarial de Zaragoza ha permitido conocer la forma en que se realizaban estos contratos y profundizar en el estudio de las personalidades implicadas en los hechos que se relatan.

PAlabRaS ClaVE: Marbiztorá, rabinato, Zaragoza, rabí Jucé ben Josuá, Salomón Bonafed, siglo XV.

\section{SUMMARY}

The appointment of the Marbiztora (Rabbi) of the Jewish community in mid-fifteenth c. Saragossa gave rise to a conflicting situation at the time of the renewal of the office between the two candidates (R. Juce ben Josua and R. Elias) and their supporters. The conflict was finally settled with the appointment of the first one, a Sicilian Rabbi that could rely on the support of prince Juan, the king's deputy in the kingdom of Aragon. The documentary evidence has importantly improved our knowledge on the legal procedures followed in these appointments, and provided new information on some of the individuals involved in the events described.

Keywords: Marbiz Torah, Rabbinate, Saragossa, R. Juce ben Josua, Solomon Bonafed, fifteenth century. 